\title{
The fate of nutrients and heavy metals in energy crop plantations amended with organic by-products
}

Article

Accepted Version

Creative Commons: Attribution-Noncommercial-No Derivative Works 4.0

Galbally, P., Finnan, J., Ryan, D., Fagan, C. C. and McDonnell, K. (2019) The fate of nutrients and heavy metals in energy crop plantations amended with organic by-products.

Environmental Technology \& Innovation, 15. 100434. ISSN 2352-1864 doi: https://doi.org/10.1016/j.eti.2019.100434

Available at https://centaur.reading.ac.uk/85174/

It is advisable to refer to the publisher's version if you intend to cite from the work. See Guidance on citing.

To link to this article DOI: http://dx.doi.org/10.1016/j.eti.2019.100434

Publisher: Elsevier

All outputs in CentAUR are protected by Intellectual Property Rights law, including copyright law. Copyright and IPR is retained by the creators or other copyright holders. Terms and conditions for use of this material are defined in the End User Agreement.

www.reading.ac.uk/centaur 
Central Archive at the University of Reading

Reading's research outputs online 


\section{Accepted Manuscript}

The fate of nutrients and heavy metals in energy crop plantations amended with organic by-products

Paul Galbally, John Finnan, Declan Ryan, Colette C. Fagan, Kevin McDonnell

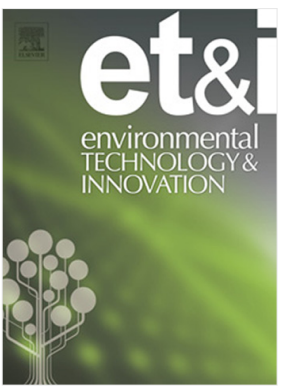

PII:

S2352-1864(18)30421-8

DOI: $\quad$ https://doi.org/10.1016/j.eti.2019.100434

Article number: 100434

Reference: $\quad$ ETI 100434

To appear in: Environmental Technology \& Innovation

Received date: 11 September 2018

Revised date: 11 July 2019

Accepted date : 17 July 2019

Please cite this article as: P. Galbally, J. Finnan, D. Ryan et al., The fate of nutrients and heavy metals in energy crop plantations amended with organic by-products. Environmental Technology \& Innovation (2019), https://doi.org/10.1016/j.eti.2019.100434

This is a PDF file of an unedited manuscript that has been accepted for publication. As a service to our customers we are providing this early version of the manuscript. The manuscript will undergo copyediting, typesetting, and review of the resulting proof before it is published in its final form. Please note that during the production process errors may be discovered which could affect the content, and all legal disclaimers that apply to the journal pertain. 
2 The fate of nutrients and heavy metals in energy crop plantations amended Nitı $\checkmark$ rganic

3 by-products

4

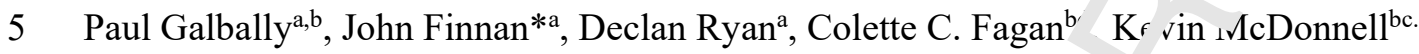

$6 \quad{ }^{a}$ Teagasc, Crops Environment and Land Use Programme, $\mathrm{C}$ ak $\mathrm{Pa}^{1}{ }^{1} \mathrm{C}$ Crops Research,

7 Carlow.

8 b Biosystems Engineering, School of Agriculture, Fuvd Sr ence and Veterinary

9 Medicine, University College Dublin, Belfield, Dub ${ }^{1 i n} 4$, Irel nd.

$10{ }^{\mathrm{c}}$ Biosystems Engineering Ltd, NovaUCD, Belfield

11

${ }^{\mathrm{d}}$ Department of Food and Nutritional Sciences, Universı.; of Reading, PO Box 226,

13 Whiteknights, Reading RG6 6AP

14

15

16

17

18 *Corresponding author. T 1: ' J35, 59 9170253; Fax: 00353 (59) 9142423. Email

19 address: john.finnan@ter xasc.ie

20

21

22

23

24

25

26

27

28 
2 Keywords: Mass-balance; overland flow; groundwater quality; soil quali ${ }^{+} y$; ᄂ ' 'solids;

3 distillery effluent; Miscanthus $x$ giganteus; short rotation coppiced willo $\checkmark$.

4

5

6

7

8 Abstract

9 Organic by-products (OB) can provide nutrition to energ, iops sut there is a potential

10 risk of pollution to soil, groundwater $(\mathrm{GW})$ and surface w. ter (SW). A mass-balance

11 inventory for two energy crops spread with biosolı. (BS) and distillery effluent (DE)

12 was created in order to study the fate of nutrients. 'insolids and distillery effluent (DE)

13 were spread on both Miscanthus $x$ gigan " $s$ and short rotation coppice willow

14 (SRCW). Applications were conducted at raus of $100 \%, 50 \%$ and $0 \%$ (control) of

15 permissible $\mathrm{P}$ loads. Losses of nutrients $\left(1^{-}\right)$and heavy metals $(\mathrm{Cd}, \mathrm{Cu}, \mathrm{Cr}, \mathrm{Pb}, \mathrm{Ni}$,

16 and $\mathrm{Zn}$ ) to groundwater and or erland low (OLF), and crop uptake were determined.

17 Total inputs (from soil, OB .mendmt.1t and atmospheric deposition ) and losses were

18 calculated and compared The ${ }^{\prime}$ ' est input was from the soil, the smallest input was

19 atmospheric deposition. The in.gest output was crop off-take; the smallest was loss to

20 OLF. Elemental $u_{r} \cdot k_{j}$ by Miscanthus was lower than that of willow but losses to

21 groundwater an ov rlar 1 flow was similar for both crops. This study has shown that

22 organic byr oduct can be used to enhance the nutrition of energy crops without

23 deleterior en. $\cdots$. mental consequences. 
7 Energy crops provide a fast growing supply of renewauiu ene gy which can replace

8 fossil fuels and mitigate emissions of greenhouse grses (Fin an et al., 2012; Murphy et

9 al., 2014). However, energy crop plantations can als, offer other services to society

10 such as the treatment of organic wastes and Wa ${ }^{\circ}$ waters (Dimitriou et al., 2006;

11 Rosenqvist et al., 1997; Figala et al., 2015).

13 Willow (genus Salix, family Salicaceae) (Aı $u$ us 1997) is a native plant in Ireland. The

14 high transpiration and low $\mathrm{r}$ ttrient equirements of willow (Hasselgren, 1998)

15 facilitates disposal of large $v$, lum is of watery waste (Guidi et al., 2008). Short rotation

16 coppice willow (SRCW) xhibits o od juvenile growth with yields of 7-12 t DM ha-1 $\mathrm{yr}^{-}$

$17{ }^{1}$ in Ireland when grow ${ }^{m}$ as shor i rotation coppice (Caslin et al., 2015b; Dieterich et al.,

18 2008). It is also the ht that the high transpiration rate and composition of willow

19 allow it to phytc $\cdot$ m diat , soils receiving OBs (Hasselgren 1998; Dimitriou, 2005).

21 Miscant _. (Mıu unthus $\times$ giganteus Greef J. M., Deuter ex Hodk. and Renvoize) is a

22 perennic ' Sout 'east Asian C4-grass which is established by planting rhizomes from

23 exist $\cdot g$ plants (Jones and Walsh, 2001). The crop can be used for bioremediation

24 (Figala et al., 2015) and can produce yields of up to $12 \mathrm{tha}^{-1}$ in Irish conditions; the 
1 crop's useful lifetime is approximately 20 years (Caslin et al., 2015a). Both

2 Miscanthus and SRCW are leading candidates for commercial energy ir Irt. nd and

3 elsewhere (Caslin 2015a; 2015b; Rosenqvist et al., 1997; Clifton-Brow \& et : 1., 2007).

4

5 Energy crops, as non-food crops offer a means of disposing of $r \mathrm{~B} \subset+$ faı $\mathrm{mland}$ as the

6 risk of direct contamination to the food chain is minimal (Dimi riou et al., 2006).

7 Energy crops are usually resilient and can often remove hrovy

8 toxins from soil with minimal effects on themselves (Britı und G rstang 2002; Figala et

9 al., 2015). Tsadilas (2005) claims that OB amendmes t aids crop nutrition and

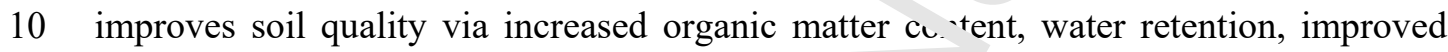

11 soil structure and better infiltration. Energy crops - tilise nutrients to maximise yield

12 although nutrient requirements are low compa. d to other crops (Caslin et al., 2015a;

13 2015b). The use of sewage sludge and w stewater to fertilize SRCW offers both

14 environmental and economic benefits though decreased fertilization costs and

15 increased biomass production ( 1 imitrio and Rosenqvist, 2011). Additionally, the use

16 of SRCW for the bioremed ${ }^{\text {}}$ tior of effluent from rural waste water treatment plants

17 offers an effective and $\mathrm{pr}^{-}$stical $\iota$, tment for wastewater management (McCracken and

18 Johnston 2015).

19

20 However, there are con erns that applications of OBs may result in the leaching of 21 pollutants tr groui 1 waters (GWs) or runoff to surface waters (SWs) (Merrington 22 2002). P. $1 d-u_{\mu}$ of both nutrients and HMs in soil receiving BS amendment is of 23 particula. conc in (McBride, 1995; 2003). Incorrect application of fertilizer can result 24 in exu 's nutrients in soil (Addiscott, 2005) which also applies to OBs (though nutrient 25 content and release profiles differ). Links between OB-amendment and SW pollution 
1 have already been identified (Epstein 2003; Korboulewsky et al. 2002); however,

2 studies with wastes such as distillery effluent are limited. Additionally, l: lks : atween

3 OB amendment to energy crops and GW pollution have also beer est: slished by

4 Curley (2009) and Dimitriou and Aronsson (2004).

5

6 Increases in nutrients and HMs in soil have been noted follov ing ap lication of OBs in

7 several studies (Haynes, 2009). Incorect amendment of $9 B$ s .... therefore result in

8 build-ups of HMs. Tian (2006) identified OB constitut...s the contaminate soil and

9 result in loss of $\mathrm{NO}_{3-}-\mathrm{PO}_{4}^{3}-, \mathrm{HMs}$ and organic mrtter to $\mathrm{S} \mathrm{V}$. The presence of these

10 constituents in DE and BS raises concerns regard $1_{\iota_{c}}$ impacts from OB application

11 (Haynes, 2009; Merrington 2002). However, bu ${ }^{\cdot 1} \mathrm{~d}$-up of HMs in soil after OB

12 application may be mitigated by the bicreme' ation capacity of energy crops which

13 have been reported to have good abilitv to ab. orb HMs from soil (Dimitriou et al., 2012;

14 Figala et al., 2015).

15

16 In previous decades, untreat $d$ o ganic wastes were spread to Irish farmland used for

17 food production; this ractice vas banned in the early 1990s (McGrath and

18 McCormack, 1999). Enllowing this, land filling and sea dumping were used before

19 these routes were reı. ed by European Commission (EC) directive (1999/31/EC) on

20 land filling of $\mathrm{v}$ ste and $\Xi \mathrm{C}$ directive (91/271/EEC) on sea-dumping in the late 1990s.

21 The regulati $\mathrm{ns} \mathrm{wc}$ ? introduced to improve treatment of OBs at source, and stimulate

22 sustainak' soluivils to disposal (EPA, 2008). There is relatively limited information

23 on the - viror nental impact of $\mathrm{OB}$ amendment to Irish SRCW and Miscanthus.

24 Exper $\boldsymbol{v}$ nts were therefore conducted between 2007 and 2009 to assess such impacts

25 and compare results obtained to those from other studies (Galbally et al., 2012; 2013; 
$12014 \mathrm{a} ; 2014 \mathrm{~b})$. The work was carried out with two energy crops (Miscanthus and

2 willow) and involved two different waste products (distillery effluent anu rewage

3 sludge). The results showed that there was little risk to surface /ate from OB

4 amendment on suitable sites (Galbally et al., 2014a\&b) although il ras ivund that

5 amendment could lead to groundwater contamination in certain 'nst nces (Galbally et

$6 \quad$ al., 2012;2013).

8 The objective of this present study was to study the faı of $t^{1} a$ nutrients and heavy

9 metals applied to energy crops in OB amendments in the context of all inputs and

10 outputs of nutrients and heavy metals to the soil-crop- 'ater system. In order to achieve

11 this objective, a mass-balance approach was usea ' create a complete inventory of

12 nutrient and heavy metals entering and leaving : e system.

\section{$17 \quad 2.1$ Study Area}

18 The experiments were $c \mu{ }^{"}$ icted at Oak Park Research Centre, Carlow, Ireland. The

19 facility (52 $51^{\prime} 55^{\prime \prime} \mathrm{N}$ lat ${ }^{\circ} 54^{\prime} 43^{\prime}$ ' W long) occupies 350 ha and is situated 55.8 meters

20 above mean sea lf vel (Aır'SL).

21 All experiments $\mathrm{w} \cdot \mathrm{c}$ nducted on a soil type known as the Athy Complex (Conry and

22 Ryan, 1968, The p rent material of this soil are calcareous, fluvio-glacial gravels of

23 Weichs 1 Age, omposed mainly of limestone with small proportions of sandstone and

24 granite. Thıu horizons are described; an upper horizon with a depth of approximately

$2525 \mathrm{~cm}$ c sscribed as a sandy loam, a second horizon with a depth of between 25 and 85 
$1 \mathrm{~cm}$ described as a gravelly sandy loam and a third horizon below $85 \mathrm{~cm}$ consisting

2 mainly of coarse sand.

3

\section{$4 \quad 2.2$ Plot establishment}

5 Twelve plots were laid out in total. In 2006, six plots were lai ou in plantations of

6 Miscanthus (established in 1993), three plots in the Barley F 1 eld (FF) (52 $51^{\circ} 47.9$ ” N

7 lat $6^{\circ} 90^{\prime} 86.6^{\prime \prime} \mathrm{W}$ long) for application of DE and three in the :

8 (NAM) $\left(52^{\circ} 51^{\prime} 31.7^{\prime \prime} \mathrm{N}\right.$ lat $6^{\circ} 90^{\prime} 77^{\prime}$ W long) for BS. Alı risco ithus plots had an area

9 of 0.1174 ha $(42 \mathrm{~m} \times 28 \mathrm{~m})$. In 2007, a plantatirn of mi ed $S$. Viminalis L. and $S$.

10 Schwerinii L. willow hybrids was established in the 1. - Avenue Meadow (FAM). All

11 SRCW plots were $0.0588 \mathrm{ha}(14 \mathrm{~m} \mathrm{x} 42 \mathrm{~m})$ in dime. ion. Six plots were established in

12 this plantation (arranged in two sets of three); $\mathrm{t}_{1}$ ee at $52^{\circ} 51^{\prime} 29.83^{\prime \prime} \mathrm{N}$ lat $6^{\circ} 54^{\prime} 19.94^{\prime \prime} \mathrm{W}$

13 long for DE and three at 52 51'31.7" N lat 5 $54^{\circ} 14.15^{\prime \prime} \mathrm{W}$ long for BS. The SRCW

14 plots were spaced with 5 meters between t.eir facing edges, to minimize interaction

15 across plot surfaces.

16

17 Plots were labelled acco ding to reatment; i.e. plots subject to DE applications are

18 denoted $\mathrm{DE}_{\mathrm{x}}$ and $\mathrm{BS}$ ar - denoteu $\mathrm{BS}_{\mathrm{x}}$, the subscript $x$ denotes treatment application level

$19(0,50,100 \%)$. Codes * $:$ preceded by an "M" or "W" to indicate Miscanthus or SRCW,

20 respectively (e.\& $M \cdot 3 S_{x}{ }^{\prime}$

$22 \quad 2.3$ Clim … Cunutions

23 Ireland $\mathrm{L} \backsim$ a te nperate climate dominated by Atlantic weather systems and typified by

24 mild, . 'e $i$-round precipitation. This results in soils that rarely dry out and are saturated

25 where drainage is poor (Keane and Collins 2004). Precipitation is low intensity; most 
1 agricultural soils drain well and do not become waterlogged. A summary of conditions

2 during experiments is presented in Table 1 . Climate conditions were slig' dly : : fferent

3 for the crops because of start times and durations of experiments; how vver prevailing

4 conditions were the same. Data was obtained from Met Eiru. nn's synoptic

5 meteorological station in Oak Park. Temperature and rainfal we e avove 30-year

6 averages (1960-1990) during the 30 month experiment \& peri ${ }^{2}$. Atmospheric

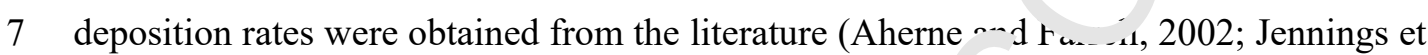

8 al., 2003; Nicholson et al., 2003). Average deposition ratev are p esented in Table 2.

9

$212015 b)$.

22 Biosolid (Tabıu $+\& 6$ ) were spread by a disc-spreader during the experimental-period.

23 Annual reatm nt-rates varied due to variation in P-content and dry matter content of 24 each ' $\mathrm{a}$ ' $\mathrm{ch}$. The spreading duration differed between Miscanthus (30 months) and 25 willow plantations, the duration being lower for willow plantations (20 months). 
1 The DE was spread during the September-October period (DE materials was not

2 available prior to this period) using an irrigation system. The total DE-am nau ' (and a

3 breakdown of constituents) are provided in Tables $3 \& 5$. Further details are vailable in

4 Galbally et al. (2012, 2013, $2014 \mathrm{a} \& b)$.

5

6

7

$8 \quad 2.5$ Monitoring of Losses

9 The quantities of nutrients (N\&P) and $\mathrm{HMs}(\mathrm{Cu}, \mathrm{Cr}$, nh, Ni and $\mathrm{Zn})$ lost to $\mathrm{GW}$

10 (Galbally et al., 2012 and 2013) and SW via $\mathrm{OL}^{\top}$ (Ga' ha' $y$ et al., 2014a and 2014b)

11 was quantified. Concurrent with monitoring $C$ " and $\supset W$, crop and soil samples were

12 obtained from each treatment prior to (and fo. 'ow. so; OB applications.

13

14 2.5.1 Groundwater Sampling

15 A series of three wells were drille ... ach plot to obtain groundwater samples, samples

16 were extracted once per month ana rer bulked, further details are provided in Galbally

17 et al., (2012).

18

19 Volumes of water ngr ssing to groundwater were calculated by first calculating

20 effective rainfall 1 y subtracing overland flow and evaporation from precipitation. In the

21 case of treatments an ar ded with distillery effluent, volumes of DE added were added to

22 precipitation amoun s. Curneen and Gill (2016) reported that evapotranspiration from

23 willow ystems in Ireland substantially exceeded reference evapotranspiration during

24 sum months. On the basis of their figures, it was conservatively assumed that

25 referenc evapotranspiration values for both crops doubled during the months of

26 August, September and October but were equal to reference evapotranspiration figures 
1 for the remaining months of the year. Effective rainfall was then multiplied by a

2 recharge coefficient which reflects the permeability of the subsoil. It was ssu. ${ }^{\circ}$ d that

3 the subsoils under the study area had a high permeability correspondi $\mathrm{g}$ tr Irish soils

4 with a recharge coefficient of 0.81-0.85.

5

6

$7 \quad$ 2.5.2. Over Land Flow (OLF) Samples and Data

8 The occurrence and duration of overland flow events wue co iected to data loggers

9 fitted to sensors designs to record OLF events. Both basic ' rab' samples and samples

10 which were proportionally accurate representations $f$ OLF were obtained. Further

11 details are provided in Galbally et al., 2014a; 2014b,.

$13 \quad$ 2.5.3. Soil and Crop Sampling

14 Topsoil samples were taken from each plov to a depth of $10 \mathrm{~cm}$; each topsoil sample

15 was a bulked-composite of $6 \mathrm{~s}^{\prime} \mathrm{o}$-samp s. To obtain four complete bulk-samples per

16 plot, 24 sub-samples were t ken using a "W" pattern; this sampling-scheme was used

17 for all plots.

18 Crop samples were oh+ained anınually at the end of each growing season by sampling

19 the above ground paı sf at least five plants per plot. Plants were cut into small pieces

20 and mixed to $\left(' \mathrm{su}^{\circ} \cdot \mathrm{a}\right.$ epresentative bulk samples before being weighed and dried.

21 Dried samp' is wer、 sent for elemental analysis.

22

\subsection{Mas Balar ie}

24 To as er, all inputs and outputs (and compare treatment effects), all results were

25 compiled into a useful whole value and therefore, a mass-balance budget was created. 
1 Analysis involved creating an inventory of the available mass of each nutrient $(\mathrm{kg})$ or

2 HM (g) (different units were used for reasons of utility) and determinin', ava ${ }^{1}$ ability

3 loss during the course of the experiment. A mass balance of nutrient ' nd $\mathrm{f}$ zavy metal

4 inputs and losses was constructed for each plot. The mass balance of nu. ient and heavy

5 metal availability included deposition by atmosphere, nutrient a d h $f$ tvy ,netals added

6 by $\mathrm{OB}$ amendment together with quantities of HMs and $\mathrm{n}^{\prime}$ irients in soil. The mass

7 balance of nutrient and heavy metal loss included losses to $\mathrm{G} \because$ und SW ( via OLF)

8 together with crop uptake. Mass in crop was dete I.t $_{1}$ ed by consideration of

9 concentration in crop samples by yield. Volatilization of $r$ trients and HMs was not

10 considered. Comparison of all plots was equalized in い $-m s$ of duration and plot areas.

11

12

13

14

15

16

\section{$17 \quad 3.1$ Introduction}

18 Mass balance results a $*$ p cented in several sections. The first section deals with

19 available nutrients a $\mathrm{Id} \mathrm{F} \mathrm{Ms}$; values for nutrients are in kilos and HMs in grams (as

20 values for nutrier $\mathrm{s}$ ware a 1 order of magnitude greater than HMs). The second section

21 looks at indivinral t, $\cdots$ ent losses to GW, OLF and crop uptake. Loss via volatilization

22 was not cons ' dered nd total losses will be greater for volatilizable species (such as $\mathrm{N}$ ).

23 Results or nutr ants and HMs are presented in separate figures (for clarity).

\subsection{Available nutrients and total metals present on plots}


1 Tables 3 to 6 show total available (and unavailable) nutrients and HMs for all plots,

2 including existing soil nutrient pools, the amount applied in $\mathrm{OB}$ and depo tea naterial

3 from the atmosphere. Distillery effluent application (Table 3 a d ") made a

4 considerable contribution to available nutrients. Atmospheric depos "ion of $\mathrm{P}$ was

5 minimal but $\mathrm{N}$ deposition was significant compared to $\mathrm{N}$ applic rion The contribution

6 of DE to total nutrients was important; increasing DE inendr ent increased the

7 quantity of nutrients available. Background levels of $\mathrm{P}$ in $\ldots$ jil $\ldots . .$. high (see Tables 3

8 to 6$)$.

9

10 Table 3 shows HMs in Miscanthus plots treated with $\cdot$ - - illery effluent; the largest pool

11 of HMs was in soil, HMs from OB application wer small; the exception was $\mathrm{Zn}$ and

$12 \mathrm{Cu}$. Atmospheric deposition provided highly s ubised metals to Miscanthus plots. In

13 general, quantities of metals from atmosph ric deposition were considerably smaller

14 than the quantities of metal applied through $\mathrm{JE}$ amendment although concentrations of

15 Zn deposited through atmospher c depos tion were significant and comparable with DE

16 amendment.

17

18 Table 4 shows source of nutrients and heavy metals in Miscanthus plots treated with

19 biosolids, as with th " iscanthus plots treated with distillery effluent, OB application

20 made a large $n$ nt but' sn to the available nutrients (particularly P). Atmospheric

21 deposition f $\mathrm{P}$ $\mathrm{w}$ 's minimal. Deposition of $\mathrm{N}$ was significant in relation to $\mathrm{BS}$

22 applicati . (5\% of all OB amendment $\mathrm{N})$. Variability in soil HM was observed

23 between indivi unal plots (and between Miscanthus sites receiving either biosolids or

24 distiı $r$ etfluent). Metals deposited through atmospheric deposition were

25 considerably smaller than the quantities of metal applied through BS amendment 
1 although concentrations of $\mathrm{Zn}$ deposited through atmospheric deposition were

2 significant and comparable with BS amendment. Atmospheric depositio \& $\mathrm{o}_{1} \nabla_{\eta}$ was

$312 \%$ of that supplied by BS amendment (at the $50 \%$ treatment rate).

5 Table 5 shows sources of nutrients and heavy metals on SRr W lots treated with

6 distillery effluent; it can be seen that $\mathrm{P}$ added to the soil- slant s'stem through DE

7 amendment was comparable to the P concentrations in $\mathrm{s}^{r^{: 1}}$ Whe...us $\mathrm{P}$ deposition was

8 low. The quantity of nutrients supplied by DE to SRCW pots $v$ as lower than supplied

9 to Miscanthus plots receiving distillery effluent ( Table 3 Rates of deposition were

10 lower (due to slight scale differences). Background s, i1 nutrients varied between sites

11 (Tables 3-6) demonstrating variability in soil condı. $n s$ at field scales.

13 Soil HMs in SRCW plots receiving dist' 'ル? e.fluent were a much greater potential

14 source of metals than amendment or $\mathrm{de}_{\mathrm{r}}{ }^{\text {sitlun }}$ (Table 5). Ratios of individual HMs in

15 willow soils was approximately e un, 'lent to Miscanthus plots.

16

17 Table 6 shows available nu. if ats nd heavy metals for SRCW plots receiving BS;

18 quantities of $\mathrm{P}$ in soil $\mathrm{w}$-re : milar to quantities of $\mathrm{P}$ added through BS amendment but

19 much higher than $\mathrm{c}$ ant ies added through atmospheric deposition. In terms of OB

20 application, rates of $N$ we

21 plots receiving $\mathrm{DE}$ \& $\bullet$ o greater concentrations of these nutrients in BS; P-applications

22 were approx nately :quivalent. The largest source of potentially available heavy metals

23 was fro 1 the sc 1 . In comparison, the quantities of potentially available heavy metals in

24 BS : ‘ndment were small. 
1 Table 6 also shows sources of input metals to SRCW plots receiving BS; and the large

2 pool of HMs bound in the soil organic matter is again evident. The cons ntla ins of

3 metals in these plots were smaller than in the corresponding Miscar hus plots or in

4 SRCW plots receiving DE (despite the latter's proximity) agaı demunstrating

5 variability in soil HMs over very short ranges. However, the amuunt of HMs

6 introduced to these plots via BS was greater than HMs ir roduc $d$ to SRCW plots

7 receiving DE via DE application.

$9 \quad 3.3$ Nutrient and heavy metal losses

11 In this section, losses of nutrients and HMs from plots . - - broken down by fractions lost

12 to crop uptake, leaching to GW and loss to OLF. r rure 1(a) shows fractions (loss to

$13 \mathrm{GW}$, OLF and crop uptake) of nutrient lnss $\mathrm{fr} 、 \mathrm{n}$ Miscanthus plots receiving DE. The

14 role of crop uptake and positive correlations beıween DE treatment rate and loss of $\mathrm{P}$

15 and $\mathrm{N}$ are evident. Crop uptake increased $w$ ith DE amendment rates. High rates of $\mathrm{N}$

16 were lost to drainage relative to $\mathrm{P}$ and 1 isses of $\mathrm{N}$ to drainage were influenced by DE

17 application rate. Crop uptak of? was lower than that of $\mathrm{N}$ but $\mathrm{P}$ losses to drainage

18 were lower than those $\mathrm{o}^{\mathrm{N}} \mathrm{N}$ but icreased with application rates. Losses of $\mathrm{N}$ and $\mathrm{P}$

19 through OLF were ver small but there was a relation between application rate and loss.

21 Figure 1(b) sho ' 1 l is o nutrients from Miscanthus plots receiving BS; loss of nutrient

22 from Miscal chus p. its spread with BS were greater than from plots to which DE had

23 been apr ${ }^{1}$ d. Ims correlates with the greater quantities of nutrients supplied by BS

24 compare. to $\mathrm{D}$ - (Tables 3 and 4). Losses of $\mathrm{N}$ to GW increased with BS application

25 rate. 1 r ever, losses of $\mathrm{P}$ to $\mathrm{GW}$ were lower than those of $\mathrm{N}$ and were unrelated to BS 
1 application rate. However, nutrient loss in OLF, although very small, was significant but

2 unrelated to application rate.

3

4

5 Figure 1(c) shows loss of HMs from Miscanthus plots recei ing DE, Zn had the

6 greatest loss rate of all metals and losses of $\mathrm{Zn}$ were domina $\mathrm{d}^{+} \mathrm{d}$ by rop uptake. Losses

7 of all metals generally increased with DE application ${ }^{\circ}$ or n...u metals, losses to

8 groundwater were greater than losses to crop uptake. Tht $\_\mathrm{n} \mathrm{pe}, 1$ in soil (Table 3) was

9 considerably smaller than the Ni pool although quartities of Ji in DE were smaller than

10 quantities of $\mathrm{Zn}$. However, loss of Ni was low compa ${ }^{d}$ to $\mathrm{Zn}$. The patterns of loss for

$11 \mathrm{Zn}, \mathrm{Ni}$ and $\mathrm{Cu}$ corresponded with $\mathrm{OB}$ amendment $1 \mathrm{c}$ 's rather than soil pools (Table 3).

12 Results suggested that this was also the case $\mathrm{w}$ a $\mathrm{Cu}$ and $\mathrm{Pb}$. Losses to OLF were very

13 small, with the exception of $\mathrm{Cu}$ and $\mathrm{Zn}$ whe losses to OLF increased with application

14 rate. The results showed that almost all tiv losses occur through leaching or crop

15 uptake up, OLF was not a majo loss pa iway for metals. indicating OLF is not a major

16 issue for metals (even for $\mathrm{mr}$ ie $\mathrm{r}$ obile species such as $\mathrm{Zn}$ ).

17

18 Figure 1(d) shows the loss or HMs to crop, GW and OLF from Miscanthus plots

19 amended with biosolı A high uptake of $\mathrm{Zn}$ and $\mathrm{Cu}$ is evident (as with Miscanthus DE

20 plots plots) whi $h v$ as $r$ iated to the level of BS amendment. Results from Figures 1c

21 and 1d shor comr nalities in how HMs are mobilized, regardless of OB type. Losses

22 of $\mathrm{Zn}$ an $-\mathrm{Zu}$ unued to be dominated by crop uptake. Losses of $\mathrm{Cd}, \mathrm{Cr}, \mathrm{Pb}$ and $\mathrm{Ni}$

23 tended $i$ be ominated by drainage losses. Losses to OLF were very small in

24 comp. ris sn to losses to drainage and crop uptake. 
1 Figure 2(a) shows nutrient losses from SRCW plots amended with DE by crop uptake,

2 leaching to GW and surface OLF loss. Comparison with Figure 1 show, tan- up of

3 nutrients by SRCW was greater than take up by Miscanthus. Nutri nt 1 ssses were

4 dominated by crop uptake although there were drainage losses in the $\mathrm{c}^{-} \mathrm{e}$ of $\mathrm{N}$ but not

5 P. In contrast, losses to OLF were very small. Figure 2(b) shov s th loso of nutrients

6 from willow plots amended with BS and their breakdown; sto cre $n$ uptake, leaching

7 through profile and loss to OLF. Again, crop uptake was mate

8 or OLF. Losses via the OLF pathway were very smalı. The sptake of nutrients by

9 SRCW on BS plots was comparable to DE plots Figure ? (a), though rates do not

10 correlate with rates of BS applied. Nutrient loss to गF was similar for DE and BS

11 plots, Leaching of nutrients to GW were comparabı hetween both types of waste.

13 Figure 2(c) shows loss of HMs from W-DE plots; when compared to Figure 1, results

14 show the higher uptake up of Zn by SRCW compared to Miscanthus for both DE and

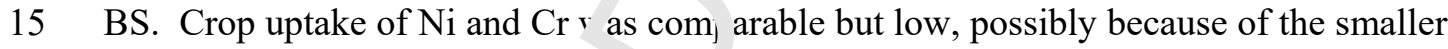

16 levels of these metals in DF Su iace Ioss of HMs via OLF from SRCW DE plots was

17 low. Differences in HM osses 4 . OLF (between Miscanthus and SRCW plots) were

18 similar to patterns of nitrient iuss. Leaching of HMs to GW from SRCW DE plots

19 (Figure 2) was lowe ${ }^{2}$ an leaching from Miscanthus DE plots (Figure 1). Figure 2(d)

20 shows total HN los es f om SRCW BS plots. Metal uptake by crop, leaching to GW

21 and loss to OLF vere similar to patterns of loss for SRCW DE treatments, with

22 significa take up of $\mathrm{Zn}$. Soil HM pools and HMs derived from OB application were

23 higher 1 - SRC $\mathrm{N}$ BS plots (deposition from the atmosphere was equivalent); however,

$24 \mathrm{HM}$. is es were lower (or equivalent) for SRCW BS plots compared to SRCW DE

25 plots , indicating lower HM mobility in BS. Based on these results, greater 
1 concentrations of HMs in BS did not automatically equate to greater HM losses from

2 plots spread with BS materials.

3

\section{Discussion}

7 By far the largest pool of (potentially available) nutrients anc met .ts is from the soil

8 which far exceeds the quantities of nutrients and heavy als i OB amendment and

9 atmospheric deposition pools. However, the vast majority o. soil HMs will be bound in

10 the soil (Haynes et al. 2009) and only a very smaı nercentage becomes bioavailable

11 (Alloway \& Jackson 1991; McGrath et al. 2008). Come OB borne nutrients and HMs

12 will also be immobile; however, a substant 1 quantity of elements in $\mathrm{OB}$ will be

13 available immediately while more becomes available over time (Haynes et al. 2009).

14 This is particularly true of HMs, organic $b_{2}$, roducts contain a very high percentage of

15 bioavailable metals (Pacyna and Jttar, 989). Although the availability of soil HMs is

16 lower than from OB or depos ion (Alıwway \& Jackson 1991), the size of this (soil) pool

17 will result in large losses f a si.. ${ }^{1}$ fraction becomes available. Metals introduced via

18 amendment were greater from $2 \mathrm{~S}$ applications than DE agreeing with previous reports

19 of the composition ${ }^{\circ}$ tr ese materials (Carton, 2007) although concentrations of $\mathrm{Zn}$ in

20 both materials w se sprr ximately equivalent.

22 Nutrients an ' .rs from atmospheric deposition will be very bioavailable as solutes

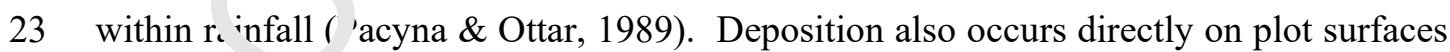

24 givin $_{2}$ th s vector a disproportionately important impact on OLF. The relatively large

25 quantities of HMs deposited on plots by the atmosphere over the experimental period, 
1 puts the potential impact of BS and DE amendments into perspective. That said, the

2 quantities of HMs derived from OB amendments (even DE) were larg $\mathrm{c}$ tı. $~$ from

3 atmospheric deposition (despite increases in atmospheric metals such as $\mathrm{P}$ ) in recent

4 years) (EPA 2008). Most metals had low deposition rates comparc to LE or BS

5 amendments; however, this was not true of all metals, particularl! tho e prusent in small

6 concentrations (such as Cd). Deposition of some HMs $r$ as cc nparable (or even

7 greater) than from DE amendment (Zn supplied by DE to ${ }^{\mathrm{I} x} \mathrm{Dt} \ldots$.. as a tenth of the $\mathrm{Zn}$

8 introduced via the atmosphere). For $\mathrm{Cu}$, this was more punnour ed (with $\mathrm{Cu}$ from $\mathrm{DE}$

9 being 5\% of deposition to SRCW DE plots) im nlying 1 E application would not

10 contribute significantly to risks of quality degrada. in from HM losses (at these

11 amendment rates).

13 Due to HM immobility in soil (Alloway and Jackson, 1991), soil pools do not

14 significantly influence short-term metal lowses, although long-term impact on crop

15 uptake and GW is importar. Surfá :e flows of HMs are strongly affected by

16 atmospheric deposition and ' $\mathrm{B}$ : pplications relative to soil pools. This is less true of

17 nutrients, as nutrient poo $^{1}$, in hei ${ }^{\circ}$ iy soil usually provide significant amounts of $\mathrm{N}$ and

18 P in bioavailable form (Merrnıgton 2002). In terms of the nutrient mass balance, the

19 total input of availabı $\checkmark$ in this work does not include available soil-N (as there is no

20 reliable Irish te $1: t^{\prime}$.e sr $1-\mathrm{N}$ status of the soils was typical for Irish grasslands (based

21 on the Inde -scale system) (Coulter and Lawlor 2008). Existing soil-N is likely to

22 contribut $\rightarrow$ tolai $-\mathrm{v}$ budgets for each crop. In terms of deposition of nutrients, there is a

23 small th 'igh inportant contribution (given almost all deposited nutrients will be

24 bioav, ils sle and remain on the surface) (Aherne and Farrell 2001); they will therefore

25 have a disproportionate impact on OLF and uptake (relative to the other sources). 
2 Previous results show that OB applications can result in nutrient loss $\left(\mathrm{G} d \mathrm{db} \mathrm{a}_{1}{ }^{-1}\right.$ et al.

$32012 ; 2013 ; 2014 a ; 2014 b)$. It is likely that deposition of nutrients is also a factor in

4 losses to OLF; however, this is equivalent across plots and difficuı ${ }^{\text {}}$ ) autect. The

5 greater uptake of nutrients by SRCW was noticeable, though ler hin, to $\mathrm{uW}$ was low

6 (and similar for both crops). Additionally, there was not a' ways clear relationship

7 between OB application and nutrient drainage loss suggesting t.... . .utrient losses were

8 influenced as much by background soil nutrient levus as by nutrients in $\mathrm{OB}$

9 applications as reported previously by Galbally et al (201.). Losses of nutrients to

10 drainage differed between the two crops as Miscu thus had greater losses of $\mathrm{N}$

11 compared to willow. Dimitriou et al., (2012) pu iously reported high P losses to

12 leaching under willow crops. Nutrient losses $\mathrm{v}$. the OLF pathway were influenced by

13 OB application but losses were very small in comparison to losses to drainage and crop

14 uptake as reported previously by Galbally et $\mathrm{al}$. 2014a \&b. Losses of HMs to OLF were

15 influenced by OB application ar 1 were : nall in relation to drainage losses. For willow,

16 HM losses were dominated ' y c'sp uptake. Cadmium, considered the most hazardous

17 element in the food chair, is reau. $y$ taken up by SRCW (Dimitriou et al., 2006; 2012)

18 and this research found that losses to drainage and OLF were miniscule in relation to

19 crop uptake. In contra ${ }^{+}$offtakes of Cd by Miscanthus were much lower, comparable to

20 drainage losses, $\mathrm{pc}$ sibl attributable to greater concentrations of $\mathrm{Cd}$ in roots and

21 rhizomes co nparec to shoots (Fernando \& Oliveira, 2004). Zn was the element which

22 was mos $^{+}$. adılı adken up by both crops, crop uptake increasing with OB application.

23 Dos Sa ${ }^{\dagger}$ os $\mathrm{I}$, tmazian and Wenzel (2004) previously reported much higher

24 conce tr tions of $\mathrm{Zn}$ compared to $\mathrm{Cd}$ in willow grown on contaminated soils. Similarly,

25 Kocon and Matyka (2012) reported much higher concentrations of $\mathrm{Zn}$ compared to $\mathrm{Pb}$ 
1 in Miscanthus grown on contaminated soils even though the concentrations of both

2 these elements in soil were equivalent.

3

4 Crop uptake was the largest nutrient output pathway for both crops " 'though willow

5 took up approximately three times the quantity of nutrients and eav muals taken up

6 by Miscanthus, thus the superior phytoextraction performa ce of willow is evident.

7 Dimitriou (2005) previously reported that willow could he usu. il phytoremediation

8 systems. Lower uptake of nutrients, and perhaps beav, met ds, by Miscanthus is

9 possibly related to the greater nutrient use efficiency of Misc nthus which is attributable

10 to its C4 photosynthetic system (Naidu and Long, 2n)4) whereas willow has a C3

11 photosynthetic system with lower nutrient use efficı ncy. Willow, typically, has higher

12 nutrient requirements compared to Misranth (Caslin et al., 2015 a\&b) while N

13 fertilization experiments which were conduc ed close to the experimental sites in this

14 study have demonstrated that willow crops have higher $\mathrm{N}$ requirements compared to

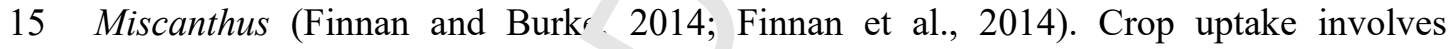

16 absorption through roots and rea ires soluble elemental forms being accessible to root

17 systems. The depth of $b$ th crop roots was $>1.5 \mathrm{~m}$ (Finch et al. 2004); however the

18 topsoil in which $\mathrm{HMs}$ tend to ve present does not extend below $25 \mathrm{~cm}$. This mass

19 balance does not acc it for nutrients and heavy metals which are absorbed by and

20 remain concent ater in he root and rhizomes systems of both energy crops. For

21 example, $\mathrm{Kr}$ ion ar. ${ }^{1}$ Matyka (2012) found that $\mathrm{Zn}$ was concentrated in the aerial parts

22 of Misca w us wiureas $\mathrm{Pb}$ was concentrated in the roots. Miscanthus and willow have

23 extensiv rooti g systems (Finnan and Burke, 2014; Matthews and Grogan, 2001;

24 Cunn, $f$, t al., 2015) which can potentially store significant quantities of nutrients and

25 heavy metals. Miscanthus has an extensive rhizome system just under the surface of the 
1 soil, the weight of the underground part of the crop can exceed that of the aerial parts of

2 the crop (Finnan and Burke, 2014). Willow plants also have an exten tve hallow

3 rooting system which is concentrated in the $0-25 \mathrm{~cm}$ depth, th $f$ preportion of

4 underground biomass is lower for willow than Miscanthus althou ' unverground

5 biomass under willow plantations can still be significant $(\sim 10 \mathrm{t}) \mathrm{M} /{ }^{\prime}$ a a ; L unniff et al.,

6 2015). However, given that underground biomass is greate for $\Lambda^{{ }^{\prime}}{ }^{\text {sscanthus than }}$

7 willow, it is possible that the Miscanthus rhizomes system nay _...e greater quantities

8 of nutrients and heavy metals than for willow. For both specif ;, nutrients and heavy

9 metals retained by roots remain on the soil-plant $\mathrm{s}^{-r} \mathrm{stem}$, at least temporarily, and are

10 not lost from the system unless translocated to aerın ${ }^{1}$ parts of the plant. This study

11 quantified losses from the system, including losses $\_$^ $\mathrm{m}$ harvesting but harvest offtakes

12 underestimate the quantity of nutrients and hear. metals absorbed by the crop.

14 The greatest source component are the suil pools (demonstrating the influence of

15 background soil conditions); ar t the lar yest output is crop uptake. The smallest input

16 is (often) atmospheric depo tior, and the smallest losses are from OLF. Atmospheric

17 deposition has a dispro ortiona. impact on OLF loss due to mobility of species

18 introduced by this pathr ay. Input from OB application is considerable for nutrients and

19 less so for metals (th $\mathrm{h} \mathrm{Zn}$ and $\mathrm{Cu}$ are supplied in large quantities by both OBs). In

20 some instances, $\mathrm{HN}_{s}$ ap lied via amendment are lower than deposition, suggesting low

21 risks of qua' 'ty des ' 'dation from OB-derived metals.

23 Leaching of nu ient and HMs to GW make up a substantial fraction of the total losses,

24 greatc t ian comparative loss to OLF (though risk profiles for GW and OLF are

25 different and needs to be considered). Loss of individual species to GW are relatively 
1 large for nutrients but much less so for metals (with exception of $\mathrm{Zn}$ ). There is some

2 correlation between the loss of (some) nutrients and HMs and the rate and ? splu tion of

3 BS and DE, implying both forms of $\mathrm{OB}$ application can impact losses. 7 nis zlationship

4 is most evident for loss to OLF and the most serious potential risk $1 \mathrm{~m}$ such losses

5 arises from loss of $\mathrm{P}$ to OLF (there was also evidence of loss of ${ }^{\prime}$ to ' $\mathrm{sW}$,. The uptake

6 of nutrient and HMs by both types of crop was strongly influ nced $\mathrm{v} v$ existing levels in

7 soil and the soil conditions; this was particularly the case fr- all t.......Ms.

8 In this study, nutrient removal at harvest (crop uptake) was th largest loss pathway.

9 Loss of nutrients at harvest, unless replaced will ler $\gamma$ to a re luction in soil fertility and

10 ultimately in yield and nutrient off-takes are the $b_{w}$ is for calculating the fertilizer

11 requirements of both Miscanthus and willow (Casi- et al., 2015a, 2015b). Thus, the

12 replacement of nutrient off-takes is the primary ason for the application of organic by-

13 products to energy crops. Energy crop fertili ‘ 1 tion may be accompanied by increases in

14 growth and productivity, nitrogen fertilizaion of willow crops grown on this site

15 increased yield by 35\% (Finna et al., 2014) while nitrogen fertilization of recently

16 sown Miscanthus crops ins eas d yield by $35-43 \%$ (Finnan and Burke 2016)..

17 However, on the same si $e$, nitru ${ }_{Ð}$ f fertilization of a mature Miscanthus crop did not

18 stimulate spring harvertod yielas (Finnan and Burke, 2014). Similarly, Adegbidi et al.,

19 (2003) found that the oplication of organic amendments increased yield of willow

20 crops by $30-38 \wedge \mathrm{v}$ nerf $\mathrm{is}$ other studies have not found any yield benefit from the

21 application ' í orga ic wastes to willow (Quaye et al., 2011; Quaye and Volk, 2013).

22 Irrespecti - of wiether willow yields are stimulated by the application of organic

23 amendm. nts, tr $\approx$ primary purpose of organic fertilization is the replacement of nutrient

24 offtak $s$,nd the prevention of any loss of soil fertility and subsequent yield reduction.

25 Secondary advantages of organic amendment to energy crops, however, arise from the 
1 disposal of potentially difficult wastes in a manner which does not contaminate the food

2 chain and in this study we have demonstrated that organic byproducts cr 1 bc 'sed to

3 enhance the nutrition of energy crops without deleterious environmental sons squences.

\section{Conclusions}

6 The quantities of nutrients and heavy metals supplied to ,oil/pl $n t$ systems in OB

7 amendments are often substantially smaller than the quan ${ }^{+: i}$ es _. uch elements in soil

8 or even the quantities supplied to the system by atıusphe ic deposition, this is

9 particularly the case for heavy metals. Losses of nutrit ats and heavy metals to

10 groundwater and surface water can increase with $\iota^{2}$ amendment but the principal

11 component of such loss pathways is often made in of elements lost from soil or

12 atmospheric deposition. Losses to grounc ater and surface water are often

13 substantially lower than crop uptake, the ma i loss pathway. Willow had much greater

14 phytoremediation potential compared to Miscanthus although nutrient losses to

15 groundwater and surface wate did $n_{\imath} t$ increase as a result of reduced uptake by

16 Miscanthus.

17

18 Organic wastes can be applied ıo energy crops without causing significant increases in

19 the quantities of nuı - ts and heavy metals entering groundwater and surface water

20 bodies. The qu: titi is of environmentally sensitive elements supplied in organic wastes

21 are typicall small - than corresponding elemental pools in soil, particularly for heavy

22 metals. Tus, ine dominant influence on the quantities of elements entering

23 groundw ter ? id surface waters are the concentrations of such elements in soil,

24 elem $n$ t deposited from the atmosphere can also have an important influence on

25 elemental flows to surface waters. Crop offtake is the principal output pathway from 
1 the system although elemental removal varies with crop type. This study has shown that

2 organic byproducts can be used to enhance the nutrition of energy c sps vithout

3 deleterious environmental consequences.

4

5

6

7

8

9

10

11

12

13

14 Acknowledgements

15 The authors would gratf ully : $k$ to acknowledge the help of Teagasc (The Irish

16 Agricultural Research Author $\omega_{-}$) and University College Dublin as well as the financial

17 assistance provide hv the Irish Department of Agriculture through the Research

18 Stimulus fund.

19 Researchers raul Galvally and Declan Ryan sadly passed away during 2017. Their

20 contribution $u^{\text {thi }}$ work was highly significant and their presence is very much missed.

21 May th $\mathrm{v}$ rest $\mathrm{i}$ peace.

22

23 References 
2 Addiscott, T.M., Whitmore, A.P., Powlson, D.S., 1991. Farming, Fertili sers 'nd the

3 Nitrate Problem. pp.170. CAB International. Wallingford. Oxfordshire. ing ${ }^{1}$ ind.

4

5 Addiscott, T.M., Gold, A.J., Oviatt, C.A., Benjamin, N., Gille D ¿., _J05. Nitrate,

6 agriculture, and the environment. CABI. UK.

7

8 Adegbidi, H.G., Briggs, R.D., Volk, T.A., White, E.H. Aurdhar son, L.P., 2003. Effect

9 of organic amendments and slow-release nitrogen frrtilizer 0 I willow biomass

10 production and soil chemical characteristics. Biomass 2ioenerg. 25(4), 389-398.

11

12

13 Aherne, J., Farrell, E.P., 2002. Denositı $\eta$ of sulphur nitrogen and acidity in

14 precipitation over Ireland: Chemistry, spat1a. distribution and long-term trends. Atmos.

15 Environ. 36, 1379-1389

16

17 Alloway, B.J., Jackson, f .P., 1y,'. The behaviour of heavy metals in sewage sludge-

18 amended soils. Sci. To+n Envirun. 100, 151-176.

19

20

21 Argus, G.W , 1997. 'nfrageneric classification of Salix (Salicacaceae) in the new world.

22 System. P... Mlunv. 52, 1-121.

23 
1 Britt, C., Garstang, J., 2002. Bioenergy Crops and Bioremediation - A Review. ADAS

2 Report. 119pp. http://ienica.csl.gov.uk/usefulreports/adasbioenergy.pdf ts cessed

$3 \quad 1 / 5 / 2013$

4

5 Carton, O., 2007. Investigation into the application and 'ng ermı impacts of

6 landspreading industrial Organic Wastes in Ireland. (V rsion 1). Teagasc/EPA.

7 Johnstown Castle, Wexford, Ireland.

8

9 Caslin, B, Finnan J, Johnson, C., 2015a. Miscc nthus - Best Practice Guidelines.

10 Teagasc/AFBI. Oak Park Crops Researcı Centre. Carlow. pp.46.

$11 \mathrm{https}: / / \mathrm{www} \cdot$ teagasc.ie/search/?q=MISCANTHUS $+\left\llcorner{ }^{\circ} \mathrm{ST}+\mathrm{PRACTISE}+\right.$ GUIDELINES

12 Accessed 1/5/2017.

13

14 Caslin, B, Finnan, J., Johnson, C., McCrac..en, A., Walsh, L., 2015b. Short rotation

15 coppice willow - Best Practice Juideli es. Teagasc/AFBI. Oak Park Crops Research

16 Centre. Carlow.

17 https://www.teagasc.ie/m dia/we _.te/publications/2011/Short_Rotation_Coppice_Best

18 _Practice_Guidelines.rdf. Accessed 1/5/2017.

19

20 Clifton-Brown, 'C Bre ^er, J., Jones M.B., 2007. Carbon mitigation by the energy

21 crop, Misca thus. $\curvearrowright$ lobal Change Biol. 13.11, 2296-2307.

22 
1 Conry, M.J, Ryan, P., 1968. Soils of Co. Carlow. Foras Talúntais.

2 https://www.teagasc.ie/media/website/environment/soil/Carlow.pdf (Accessed 7/2 ८ . Q).

3

4

5 Coulter, B.S., Lalor, S., 2008. Major and Micro Nutrient A dvic Productive

6 Agricultural Crops - 3rd Ed. pp.116. Teagasc. Johns uwn Castle, Wexford.

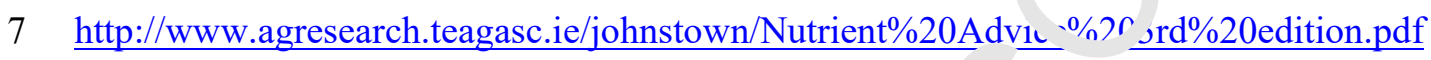

8 . Accessed 1/5/2013

9

10 Cunniff, J., Purdy, S.J., Barraclough, T.J., Castle, M., Maddison, A.L., Jones, L.E.,

11 Shield, I.F., Gregory, A.S. and Karp, A., 2015. Hz' vielding biomass genotypes of

12 willow (Salix spp.) show differences in below rr und biomass allocation. Biomass

13 Bioenerg. 80, 114-127.

14

15 Curley, E., O’Flynn, M.G.. M'Donn، 11, K.P. 2009. Nitrate leaching losses from

16 Miscanthus x giganteus - Imr ıct nn gı undwater quality. J. Agron. 8, 107-112.

17

18 Curneen, S., Gill, L.W., 20^. Willow-based evapotranspiration systems for on-site

19 wastewater effluent _. ar as of low permeability subsoils. Ecol. Eng. 92, 199-209.

20

21 Dietrich, B., innar J., Hochstrasser, T., Hepp, S., Augustenborg, C. Muller, C., 2008.

22 State and deve ${ }^{-n r}$ ent of bioenergy in the Republic of Ireland. Aspects Appl. Biol. 90, $23 \quad 27-34$.

24 
1 Dimitriou, I., Aronsson, P., 2004. Nitrogen leaching from short-rotation willow coppice

2 after intensive irrigation with wastewater. Biomass Bioenerg. 26.5, 433-44 1.

3

4

5

6 Dimitriou, I ., 2005. Performance and sustainability of short-r station energy crops

7 treated with municipal and industrial wastes. PhD Thesis. Thivt., of Uppsala,

8 Sweden.

9 Dimitriou, I., Eriksson, J., Adler, A., Aronsson, P., Verwijs , T., 2006. Fate of heavy

10 metals after application of sewage sludge and wood-'a '⿳⺈ mixtures to short-rotation

11 willow coppice. Environ. Pollut. 142(1), .160-169.

14 Dimitriou, I., and H. Rosenqvist. 2011. Sewage sludge and wastewater fertilisation of

15 Short Rotation Coppice (SRC) f ,r incre; sed bioenergy production-biological and

16 economic potential. Biomas Bir energ. 35(2), 835-842.

17

18 Dimitriou, I., Mola-Yrrego, B., Aronsson, P., Eriksson, J., 2012. Changes in organic

19 carbon and trace elem." is in the soil of willow short-rotation coppice plantations.

20 Bioenerg. Res. (3) 563572.

21

22 Dimitric , r., Nıvid-Yudego, B., Aronsson, P., 2012. Impact of willow short rotation

23 coppice $n$ wat $\lrcorner$ quality. Bioenerg. Res. 5(3),.537-545. 
2 Dos Santos Utmazian M.N., Wenzel, W.W., 2007. Cadmium and zinc acc mu. ${ }^{\text {ion }}$ in

3 willow and poplar species grown on polluted soils. J. Plant Nutr. Soil s i. 1' $0.2,265-$

4272.

5

6

7 EPA (Irish Environmental Protection Agency), 2008. Ire' ${ }^{1 \cdots} d^{\prime} s=\ldots$ rronment (State of

8 the Environment Report). pp.273. EPA Johnstornl, 'o.Wexford, Ireland.

9 http://www.epa.ie/pubs/reports/indicators/irlenv/ Arressed 7 5/2013.

10

11 Epstein, E., 2003. Land application of sewage sluu ${ }^{\circ}$. Lewis Publishers. Boca Raton.

12 FL.

15 Fernando, A., Oliveira, J.S., 20r t. Effer ts on Growth, Productivity and Biomass

16 Quality of Miscanthus $\mathrm{x}$ gig nter, of soils contaminated with heavy metals. In.

17 Biomass for Energy, Ind stry anc limate Protection: Proceedings of the 2nd World

18 Biomass Conference, D ${ }^{\text {me }}$ (Itaiy).

19

20 Figala, J., Vran vá. J., F .ejšek, K.,Formánek, P., 2015. Giant miscanthus (Miscantus×

21 Giganteus ( reef Ev Deu.)-A Promising Plant for Soil Remediation: A Mini Review.

22 Acta Un; rsitais Agriculturae et Silviculturae Mendelianae Brunensis, 63, p.245.

23 
1 Finch, J.W., Hall, R.L., Rosier, P.T.W., Clark, D.B., Stratford, C., Davies, H.N., Marsh,

2 T.J., Roberts, J.M., Riche, A., Christian, D., 2004. The hydrological impar ss o ' nergy

3 crop production in the UK. Final report.

4

5 Finnan, J., Styles, D., Fitzgerald, J., Connolly, J., Donnelly, A., 2 12. Jsııg a Strategic

6 Environmental Assessment framework to quantify the enviro' menta' impact of

7 bioenergy plans. Glob. Change Biol. Bioenerg. 4, 311-320

8

9 Finnan, J., Burke, B., 2014. Nitrogen dynamics in a mature $\Lambda$ 'iscanthus $x$ giganteus

10 crop fertilized with nitrogen over a five year period. 1, 'h J. Agric. Food Res.53(2),

$11 \quad 171-188$.

12

13 Finnan, J.,Burke, B., Carroll, J., 2014. A sho + communication on the effect of nitrogen

14 fertilization of willow on yield, combustion ^missions and greenhouse gas balance.

15 Nut. Cyc. Agroecosyst. 98.1, 1 , 7-112.

16

17 Finnan, J. and Burke, B.. 2016. N.'ogen fertilization of Miscanthus x giganteus: effects

18 on nitrogen uptake, grmeth, yieıd and emissions from biomass combustion. Nut. Cyc.

19 Agroecosyst., 106(2), , 1.249-256.

20

21 Galbally, P. Fagar, C., Finnan, J., Ryan, D., Grant, J. McDonnell, K., 2012. Biosolids

22 and disti ${ }^{11} \ldots$ e elimut nt amendment to Irish Miscanthus X giganteus plantations: impacts

23 on grour, 'water and soil. J. Env. Qual. 41(1),114-23. 
2 Galbally, P., Fagan, C., Ryan, D., Finnan, J., Grant, J. McDonnell, K., 2r 13. دiosolid

3 and distillery effluent amendments to Irish short rotation coppiced wil ow lantations:

4 Impacts on groundwater quality and soil. Agric. Water Man. 116, 193-८ ?

5

6 Galbally, P., Fagan, C., Ryan, D.,. Finnan, J., Grant, J. McD `nnell, K., 2014a.

7 Biosolids and distillery effluent amendments to Irish she-t rum... un coppiced willow

8 plantations: Impacts on overland flow and surface water quality. Agric.Water Man. 146

$9 \quad, 173-184$

10

11

12 Galbally, P., Fagan, C., Ryan, D., Finnan, I., Gı at, J., McDonnell, K., 2014b. Biosolids

13 and distillery effluent amendments to Jrish $N_{\star}$ scanthus plantations: Impacts on overland

14 flow and surface water quality. Sus. Water kual. Ecol. 3, 77-89.

15

16 Guidi W, Picciono, E., Bon ri, r., 2008. Evapotranspiration and crop co-efficient of

17 poplar and willow shor rotatio. coppice used as a vegetation filter. Bioresource

18 Technol. 99, 4832-484n

19

20 Hasselgren, K., 99`. Us : of Municipal Waste Products in Energy Forestry: Highlights

21 from Fifteen Years Txperience. Biomass Bioenerg. 15, 71-74.

22

23 Haynes, ?.J., N urtaza, G., Naidu, R., 2009. Inorganic and Organic Constituents and

24 Conta nj ants of Biosolids: Implications for Land Application. Adv. Agron. Chapter 4, $25 \quad 165-267$. 
3 Jennings, E., Mills, P., Jordan, P., Jensen, J.P., Søndergaard, M., Barr, 1., ( lasgow, J.,

4 Irvine, K., 2003. Eutrophication from Agricultural Sources - Seasu. 1 Eıiects and

5 Effects of Phosphorus. pp.61. EPA. Johnstown Cristle. Wexford.

6 http://www.epa.ie/pubs/reports/research/water/eutrophicationf omag:

7 sonalpatternseffectsofphosphorus.html. Accessed 1/5/2013

8

9 Jones, M.B. and Walsh, M. 2001. Miscanthus for er orgy ana fibre. Earthscan.

12 Keane, T., Collins, J.F., 2004. Climate Weaı 'er c ... 'Trish Agriculture - 2nd Ed. pp.395.

13 AGMET, Dublin, Ireland.

14

15 Kocon, A., Matyka, M., 2012. Ph w tractive potential of Miscanthus giganteus and

16 Sida hermaphrodita growing r'nder nor' srate pollution of soil with $\mathrm{Zn}$ and $\mathrm{Pb}$. J. Food

17 Agric. Env. 10.2, 1253-125u.

18

19 Korboulewsky, N, J upo tyet, S., Bonin, G., 2002. Environmental Risks of applying

20 sewage sludge cr npest to vinyards - Carbon, heavy metals, nitrogen and phosphorous

21 accumulation. I Elı : $\mathbf{r}_{\mathbf{r}}$ n. Qual. 31, 1522-1527.

22

23

$24 \mathrm{Ma}^{+1}$ - $\mathbf{x}$. K. B., Grogan, P., 2001. Potential C-sequestration rates under short-rotation

25 coppict ' willow and Miscanthus biomass crops: a modelling study. Aspects Appl. Biol.

$26 \quad 65,303-312$. 
2 McBride, M.B., 1995. Toxic metal accumulation from agricultural use of slun ve: Are

3 USEPA regulations protective? J. Env. Qual. 24, 5-18.

4

5 McBride, M.B., 2003. Toxic Metals in sewage-sludge amended sils nas promotion of

6 beneficial use discounted the risks? Adv Environ. Res. 8: 5-1 ${ }^{r}$.

8 McCracken, A.R., Johnston, C.R., 2015. Potential for wasw wate managemnet using

9 energy crops. Scientific Papers Series-Management Econon 'c Engineering in

10 Agriculture and Rural Development 15.1: 275-284.

11

12 McGrath, D., Fleming, G.A., Culleton, N . 20 ? . Trace Elements and Heavy Metals in

13 Irish Soils. pp210. Teagasc, Johns vwn Castle, Co. Wexford, Ireland.

14 http://www.teagasc.ie/publications/2011/82,, Trace Elements.pdf. Accessed 1/5/2013.

15

16 McGrath, D., McCormack, '.J.. 1999. The significance of heavy metals and organic

17 micropollutants in soils Projec 2 Report No.4268. pp.34. Teagasc. Johnstown, Co

18 Wexford. http:///wrw.teagasc.ie/research/reports/environment/4268/eopr-4268.pdf.

19 Accessed 1/5/2013

20

21 Merrington, J., W: der, L., Parkinson, R., Redman, M., 2002. Agricultural Pollution:

22 Environr ...tal t wublems and Practical Solutions. Chapter 3 -Phosphorus. pp.43-73.

23 Spon Prc ‘. Lo' don, U.K. 
2 Murphy, F., Devlin, G., McDonnell, K., 2014. Energy requirements and e'viru 'mental

3 impacts associated with the production of short rotation willow ( $S c i x$ s.) chip in

4 Ireland. Glob. Chang. Biol. Bioenerg. 6, 727-739.

5

6 Naidu, S.L., Long, S.P., 2004. Potential mechanisms of low-t mpera 4ure tolerance of

7 C4 photosynthesis in Miscanthus $\times$ giganteus: an in vivo ar ${ }^{-1}$ ysı. n.anta 220.1, 145-

8155.

9

10

11 Nicholson, F.A., Smith, S.R., Alloway, B.J., Carlton `mith, C., Chambers, B.J., 2003.

12 An inventory of heavy metal inputs to agricultu. 1 soils in England and Wales. Sci. of

13 Tot. Environ. 311, 205-219.

14

15 Pacyna, J.M., Ottar, B., 1989. r ontrol c nd Fate of Atmospheric Trace Metals (NATO

16 Science Series) pp.408 pages Spr nger. USA

17

18

19 Quaye, A.K., Volk, 1. ^., Hafner, S., Leopold, D.J. and Schirmer, C., 2011. Impacts of

20 paper sludge ar. ' $m$ ' nurf on soil and biomass production of willow. Biomass Bioenerg.

$2135(7), 27962806$.

22

23 Quaye, K. ar $\mathbb{d}$ Volk, T.A., 2013. Biomass production and soil nutrients in organic

24 and $\mathrm{l}_{1} \mathrm{rr}_{\text {janic }}$ fertilized willow biomass production systems. Biomass Bioenerg. 57,

$25 \quad 113-125$. 
3 Rosenqvist, H., Aronsson., P. ,Hasselgren, K., Perttu, K., 1997. Econor ‘cs r ’ using

4 municipal wastewater irrigation of willow coppice crops. Biomass Bio -arg. 12(1), 1-

58.

6

7

8 Tian, G, Granato, T.C., Pietz, R.I., Carlson, C.R., Abedin, 2., 20 ,6. Effect of long-term

9 application of biosolid for land reclamation on sirface wi er chemistry. J. Environ.

10 Quality 35 (1), 101-113.

11

12 Tsadilas, C.D., Karaivazoglou, N.A., Tsotsolis, `.C., Stamatiadis, S.,Samaras, V., 2005.

13 Cadmium take up by tobacco as afferted $\mathrm{b}$, liming, $\mathrm{N}$ form, and year of cultivation.

14 Environ. Pollut. 134, 239-246.

15

16

17

18

19

20

21

22

23

24

25 


\section{Figure Captions:}

3

4

5 Figure 1: Pathways of loss of nutrients and heavy metals from Miss $n$ thu n nots

6 applied with distillery effluent (graphs a and c) and biosolid (grap's $b \ldots{ }^{\prime} d$ ), loss of 7 nutrients given in kilograms and metals in grams for convenience. ${ }^{n}$ months.

8
Figure 2: Pathways of loss of nutrients and heavy metals fro 1 short station coppice willow plots applied with distillery effluent (graphs a and c) at ${ }^{-1}$ bios $\jmath$ lid (graphs b and d), loss of nutrients given in kilograms and metals in grar is tor convenience. 20 months. 
Table 1: Climate conditions ${ }^{\dagger}$ during the experimental period

\begin{tabular}{lr}
\hline Start Date & $17 / 03 / 2007$ \\
End Date & $31 / 12 / 2009$ \\
Total days, d. & 1019 \\
Total Rain, mm & 265 \\
Rainfall during experiment (as \% of 30 year mean) & $115 \%$ \\
Total evaporation, mm & 724 \\
Net rain (total for 1019 d.) & 638 \\
Mean daily evaporation (1019 days), mm & $1 .$. \\
Mean daily rainfall (1019 days), mm & 2.1 \\
Mean net rainfall, mm & $0 .{ }^{\circ}$ \\
Evaporation (mean for January), mm & 11.3 \\
Evaporation (Mean for June), mm & 08.7 \\
Rainfall, mean (January), mm & 109.4 \\
Rainfall, mean (June), mm & 87.3 \\
Net rain (Jan), mm & 98.0 \\
Net rain (Jun), mm & -21.5 \\
\hline
\end{tabular}

$6 \uparrow$ : Climate figures are for 25 month period of he r $x_{\mu}$-riment.

7

8

9

10

11

12

13 
3 Table 2: Atmospheric deposition during the experimental period

\begin{tabular}{cccc} 
Type & Species & Units & Values \\
\hline \multirow{4}{*}{ Nutrients } & $\mathrm{N}$ & $\mathrm{kg} \mathrm{ha}^{-1} \mathrm{yr}^{-1}$ & 12 \\
& $\mathrm{P}$ & $\mathrm{kg} \mathrm{ha}^{-1} \mathrm{yr}^{-1}$ & 0.4 \\
& & & \\
\hline \multirow{4}{*}{ Heavy } & $\mathrm{Cd}$ & $\mathrm{g} \mathrm{ha}^{-1} \mathrm{yr}^{-1}$ & 0.6 \\
Metals & $\mathrm{Cr}$ & $\mathrm{g} \mathrm{ha}^{-1} \mathrm{yr}^{-1}$ & 0.7 \\
& $\mathrm{Cu}$ & $\mathrm{g} \mathrm{ha}^{-1} \mathrm{yr}^{-1}$ & 13 \\
& $\mathrm{~Pb}$ & $\mathrm{~g} \mathrm{ha}^{-1} \mathrm{yr}^{-1}$ & 13.3 \\
& $\mathrm{Ni}$ & $\mathrm{g} \mathrm{ha}^{-1} \mathrm{yr}^{-1}$ & 1.6 \\
& $\mathrm{Zn}$ & $\mathrm{g} \mathrm{ha}^{-1} \mathrm{yr}^{-1}$ & 235 \\
\hline
\end{tabular}

4

5

6

7

8

9

10

11

12

13

14

15

16

17

18

19

20 
1

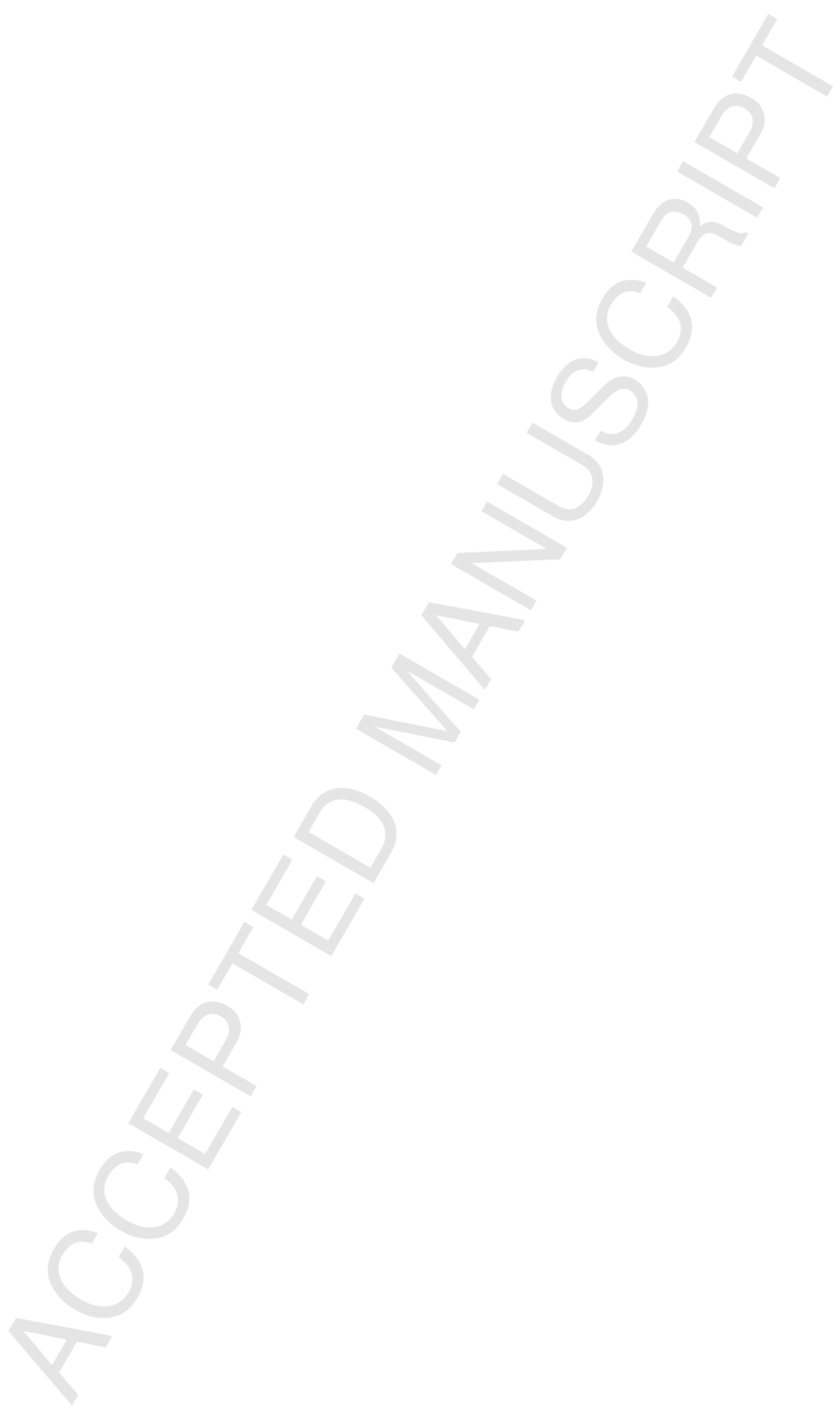




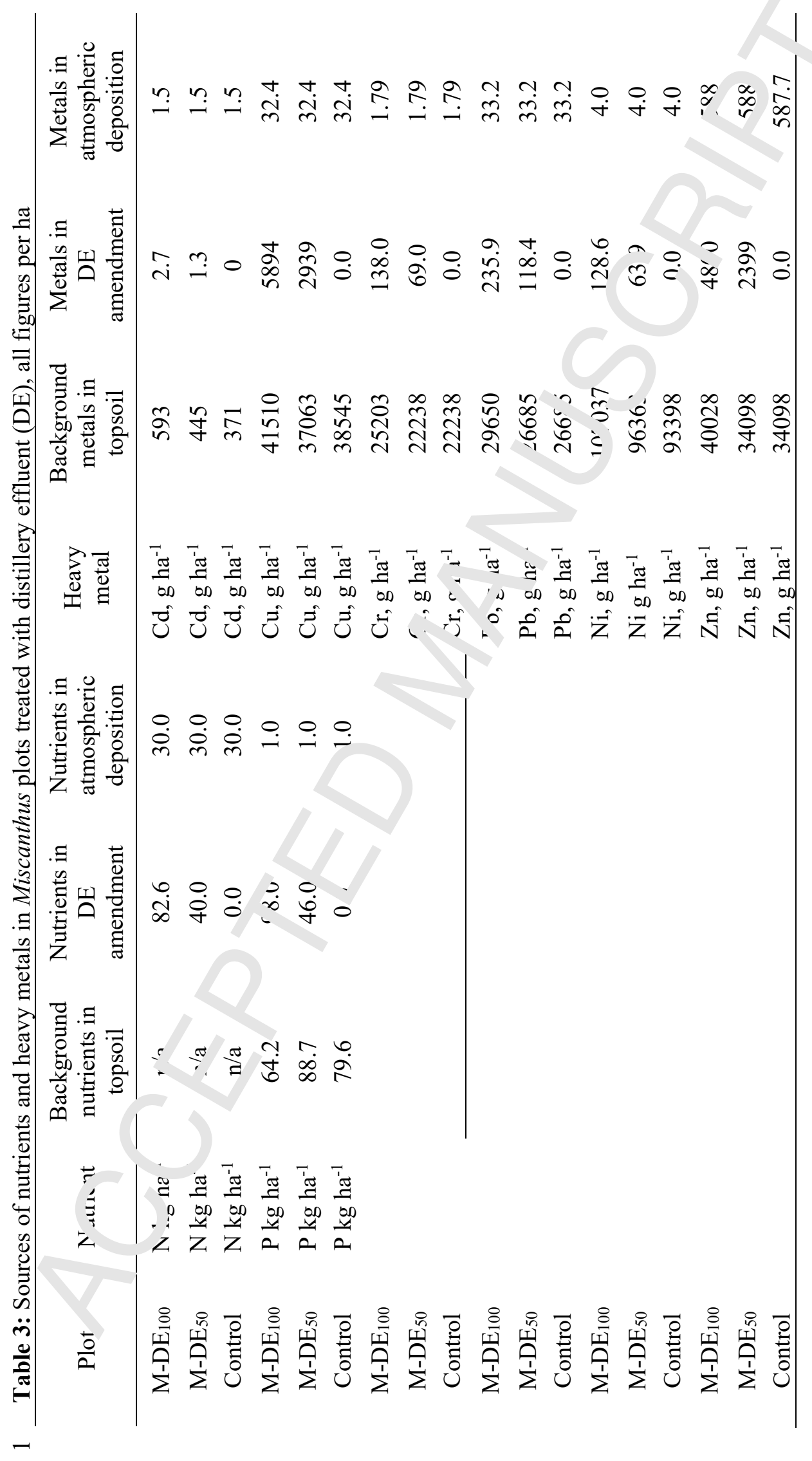




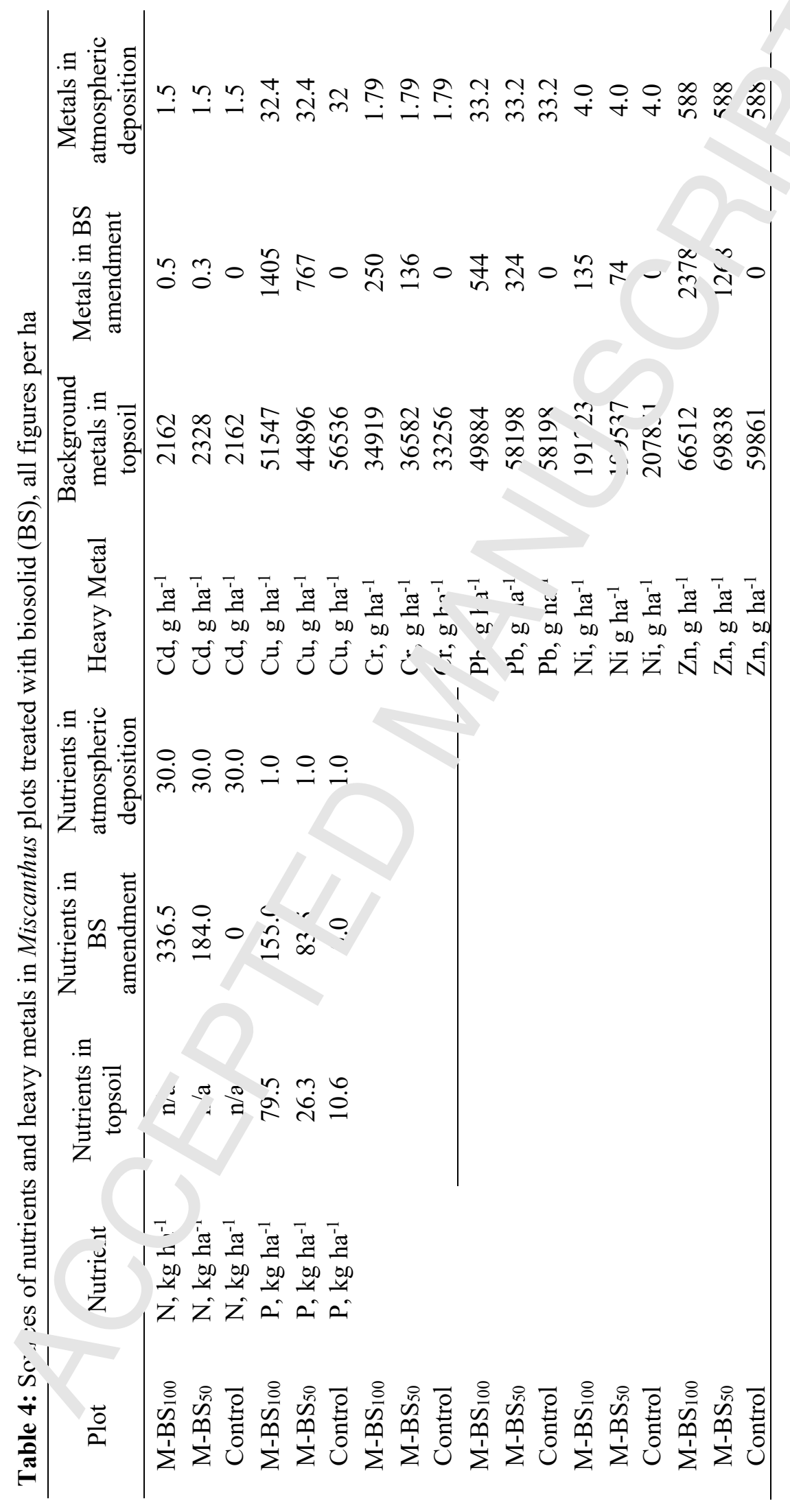




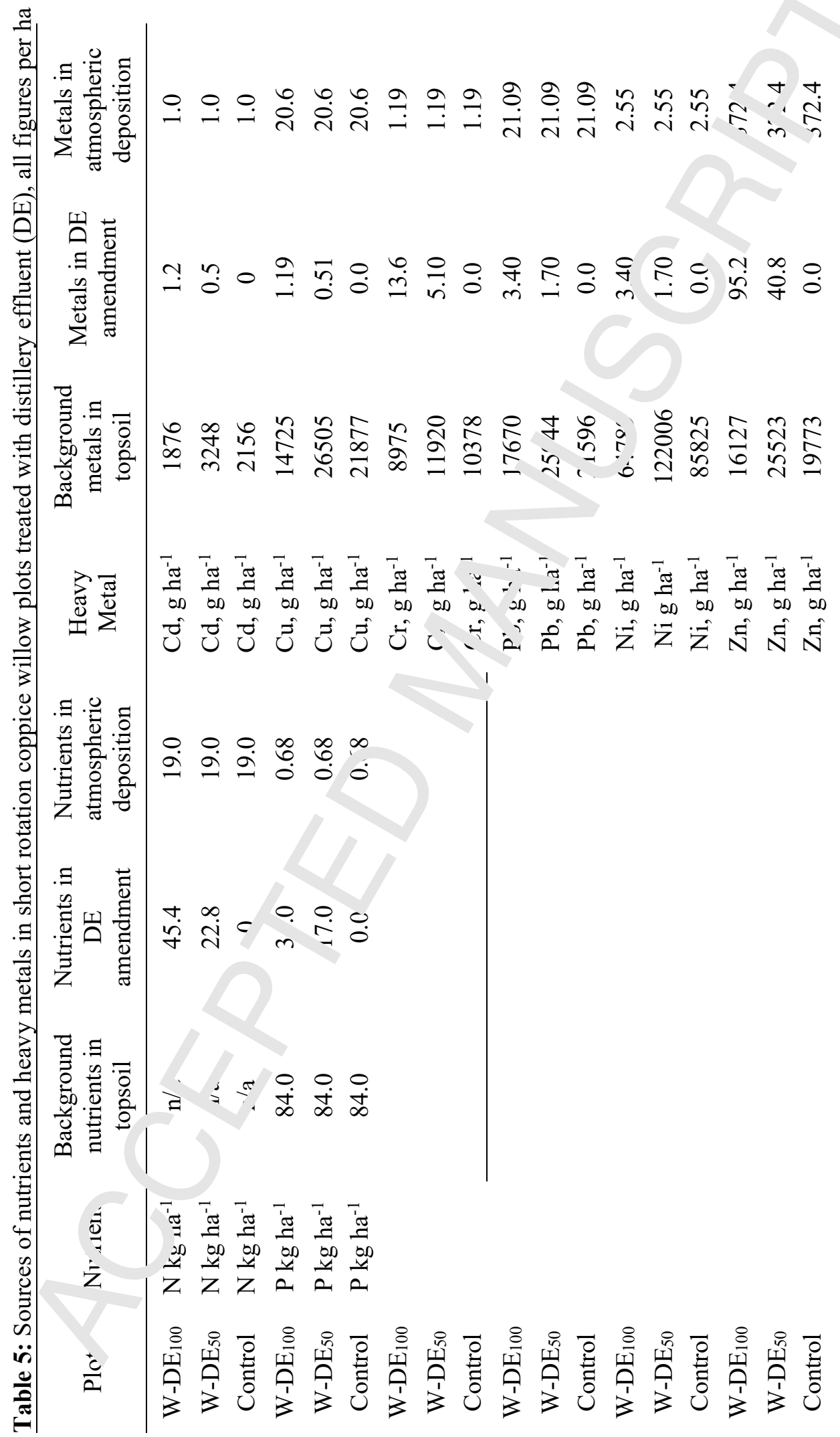




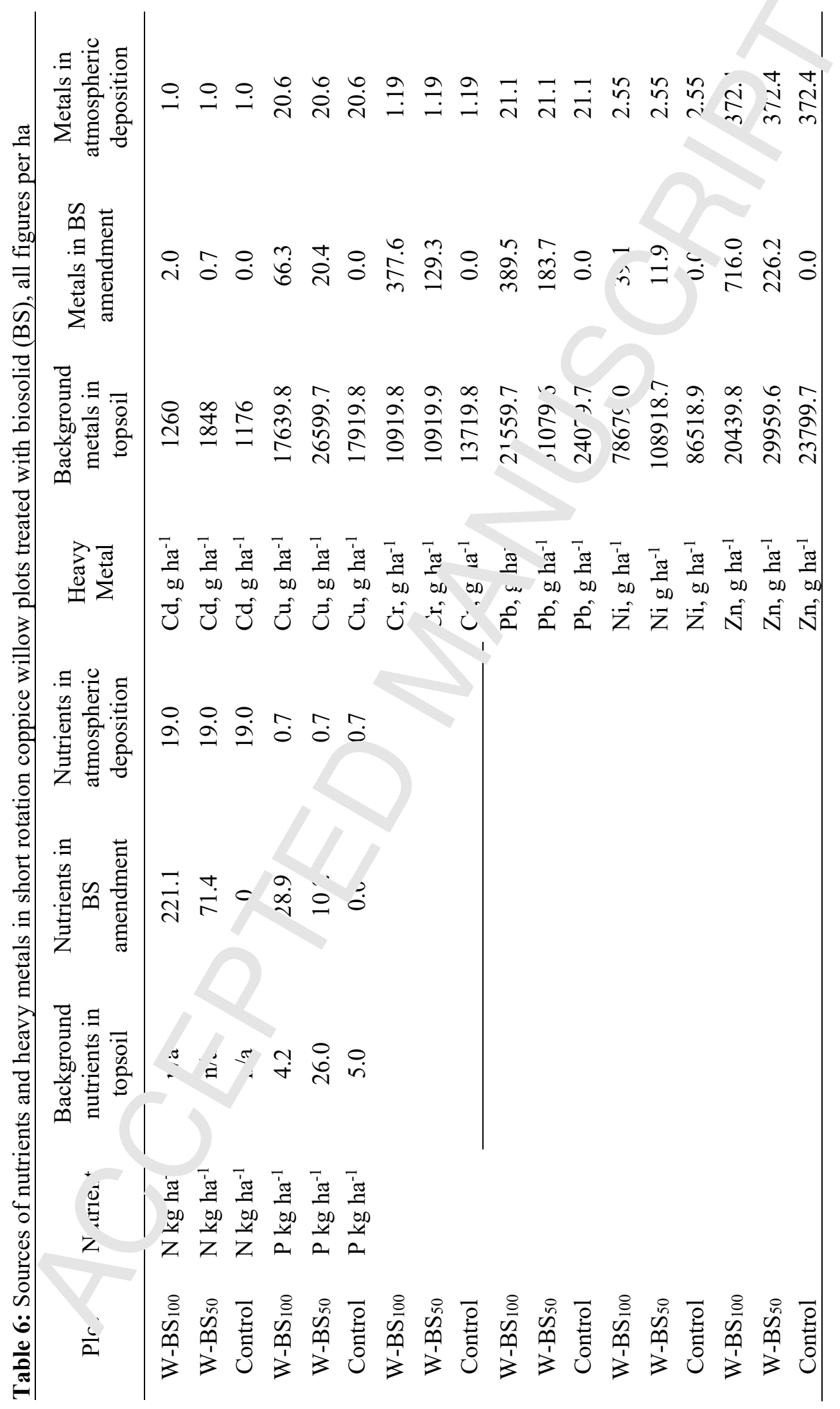


1 


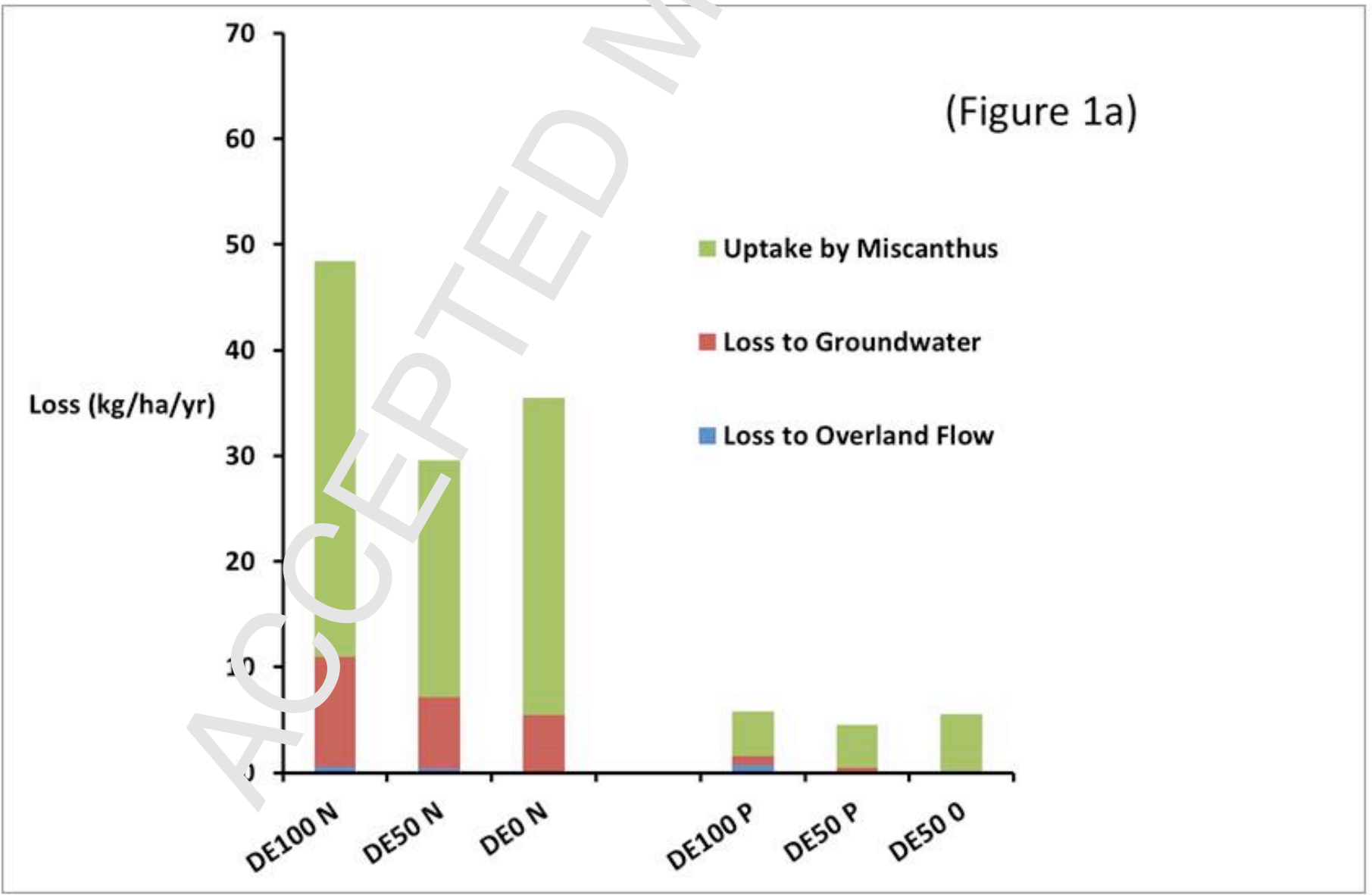




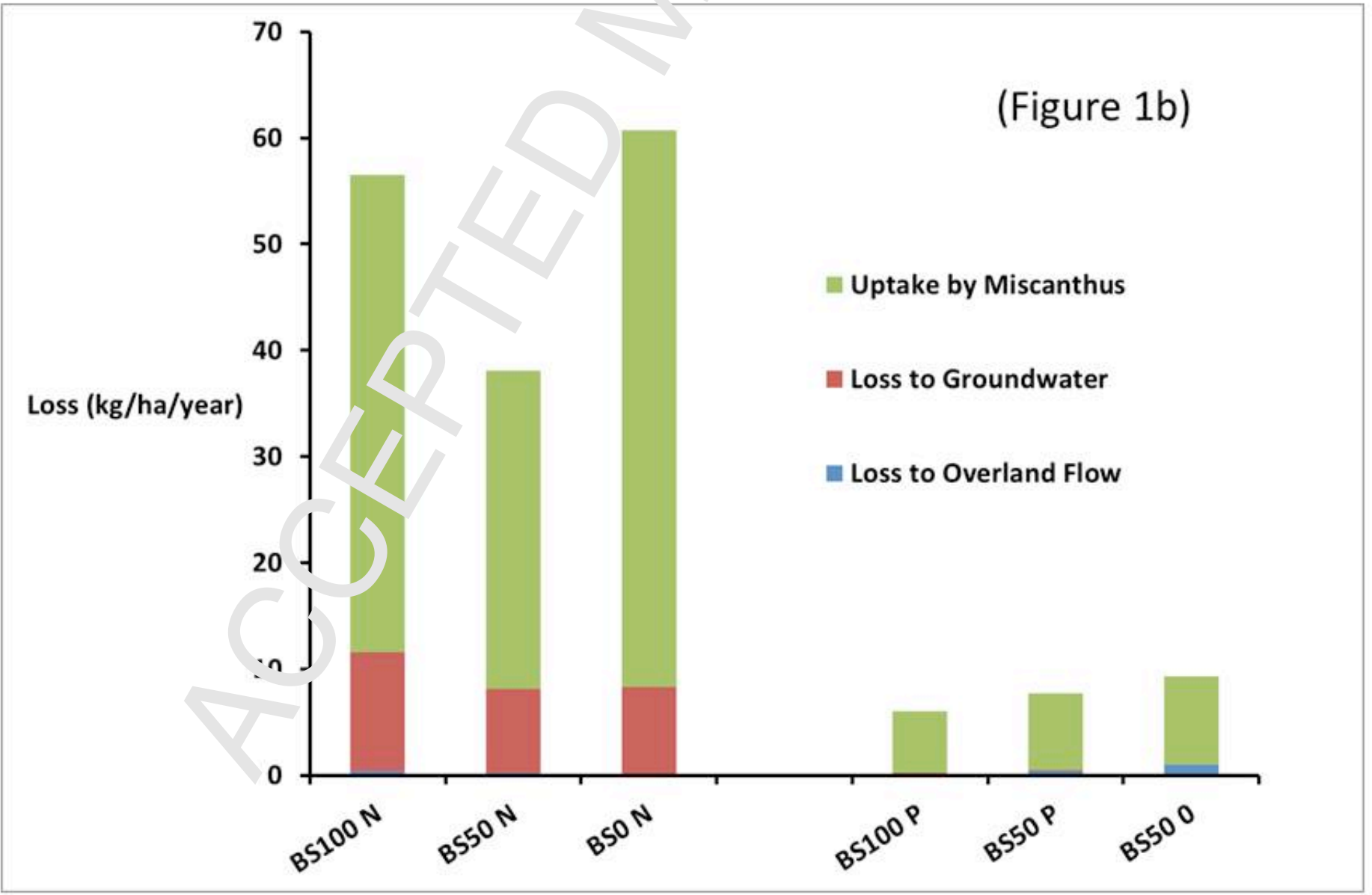




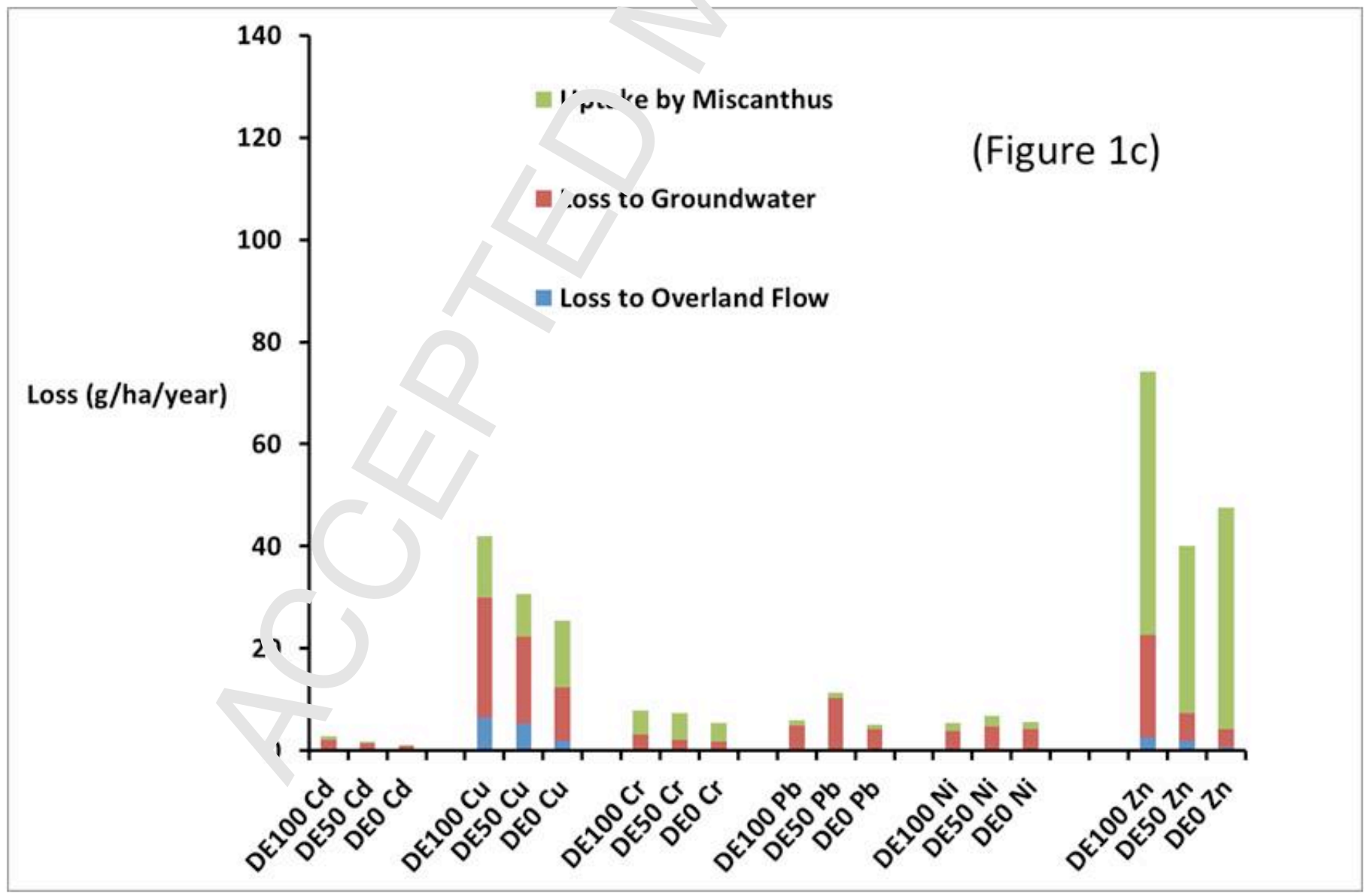




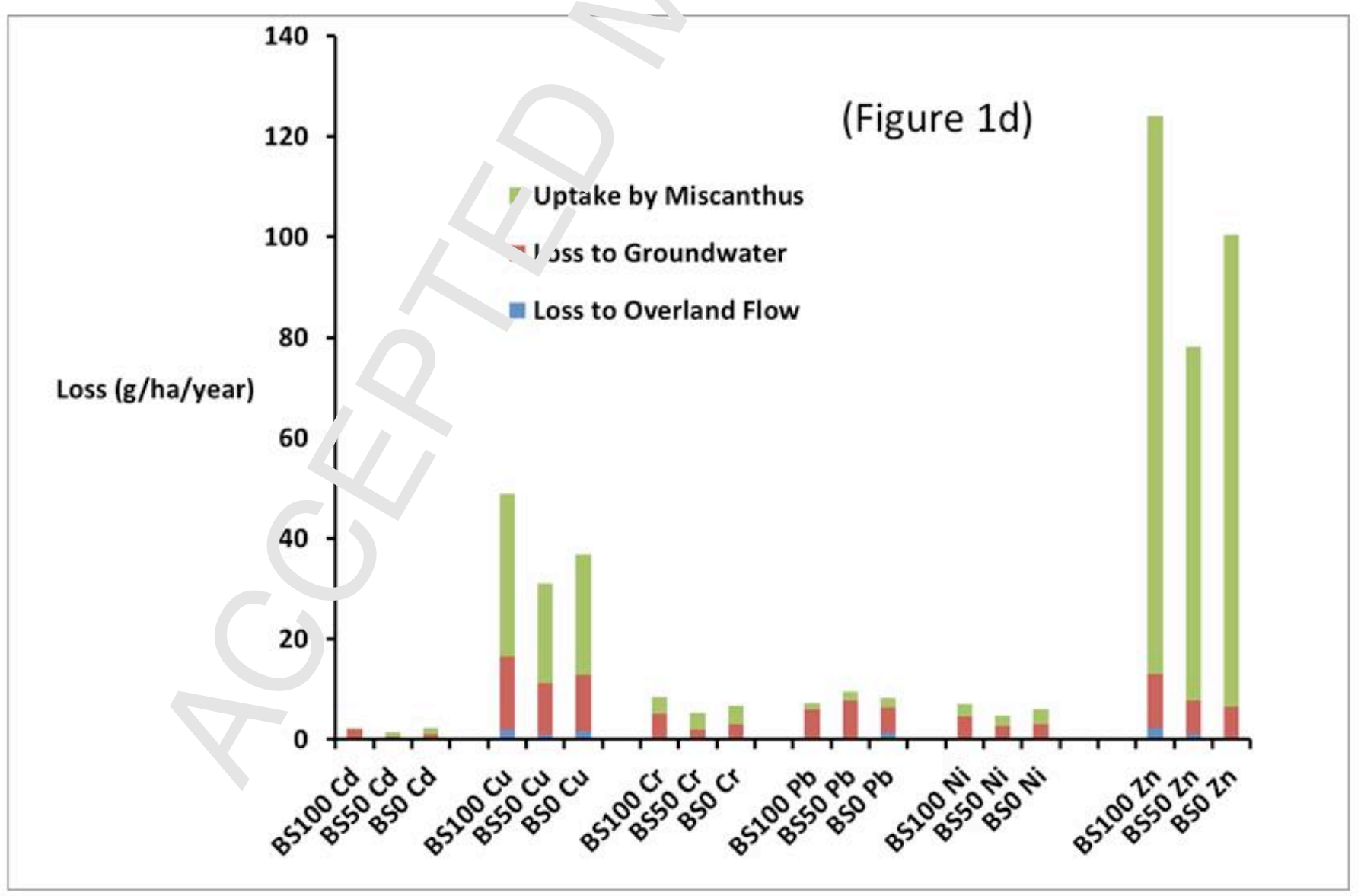




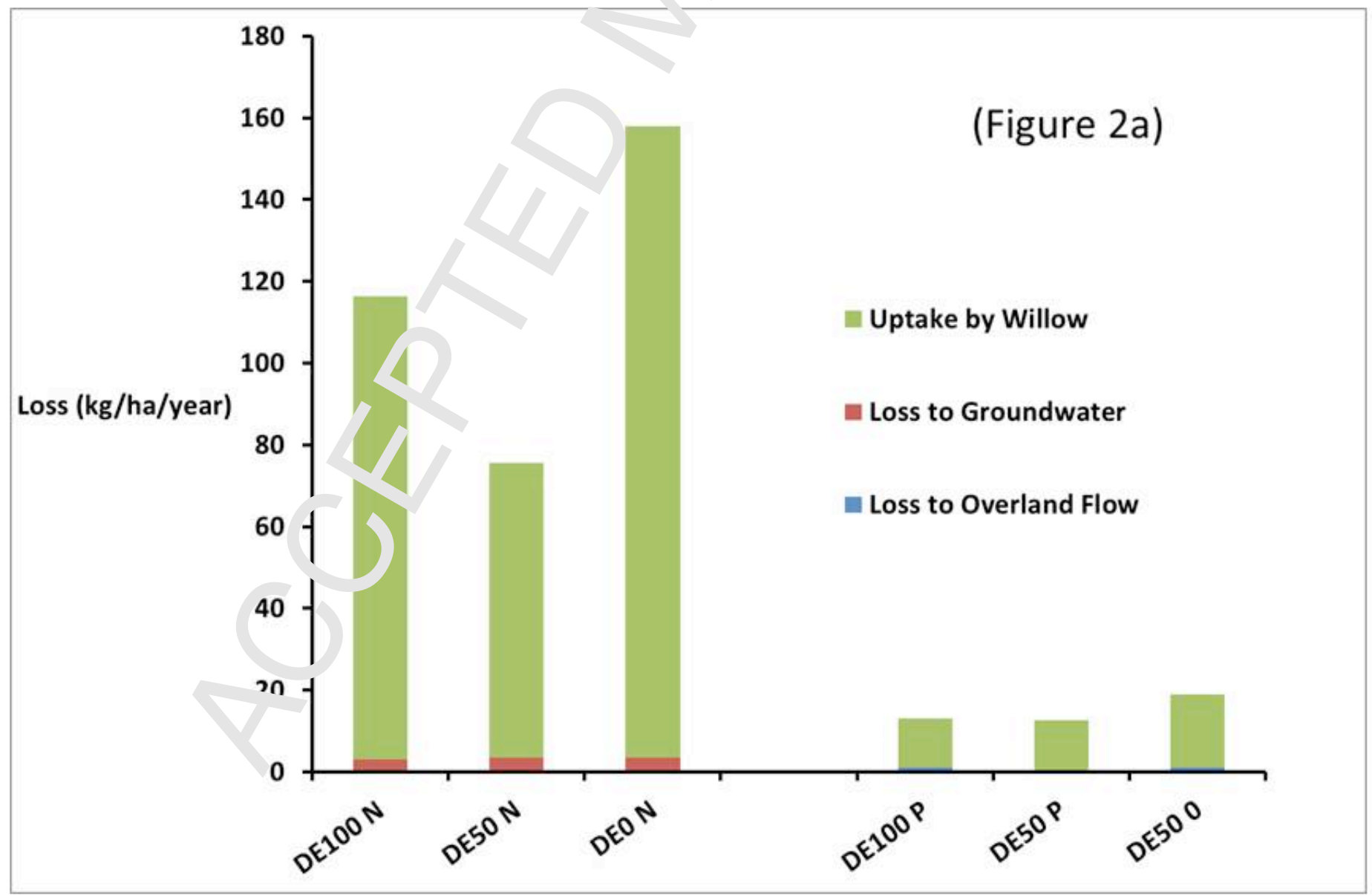




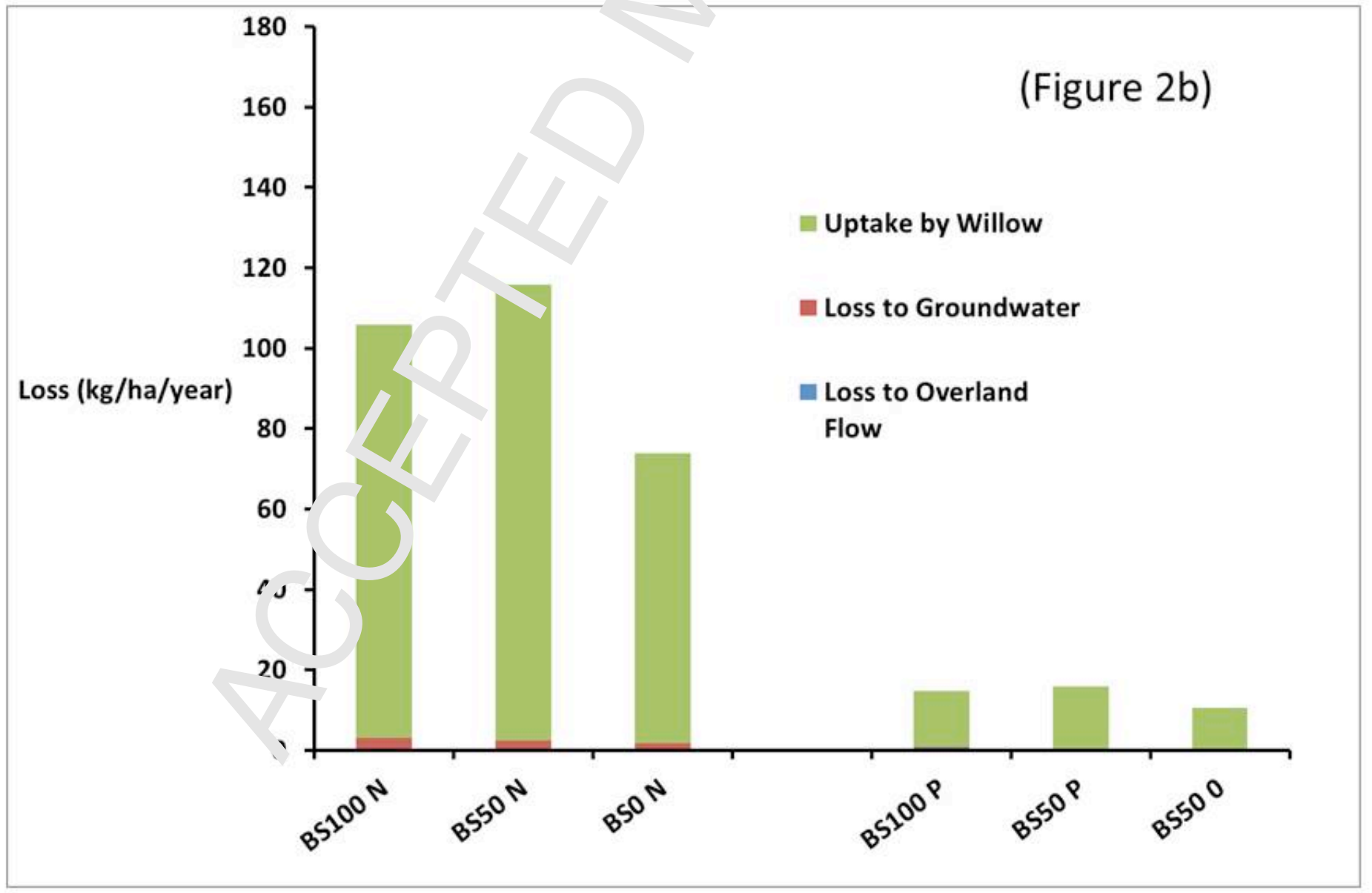




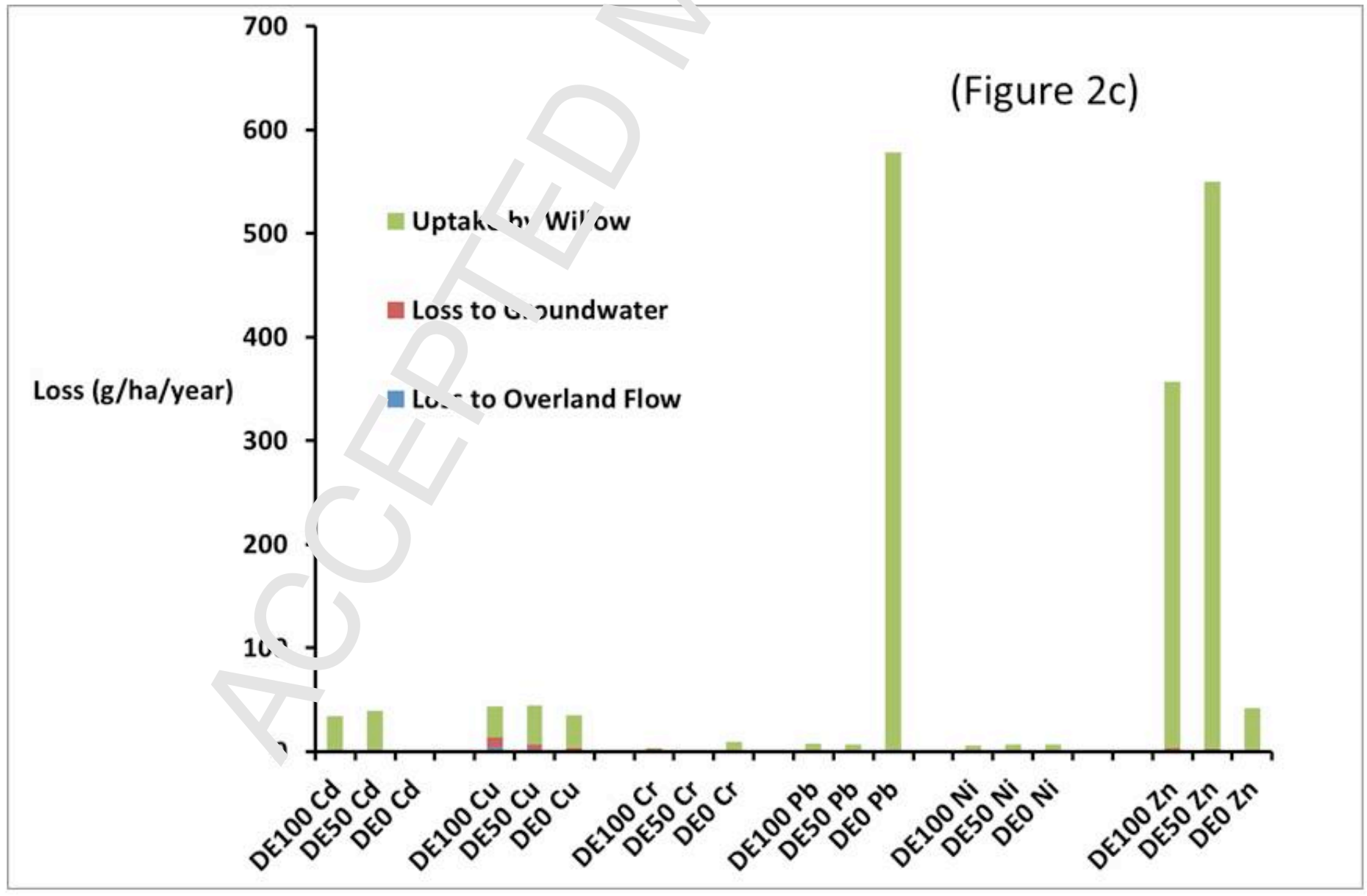




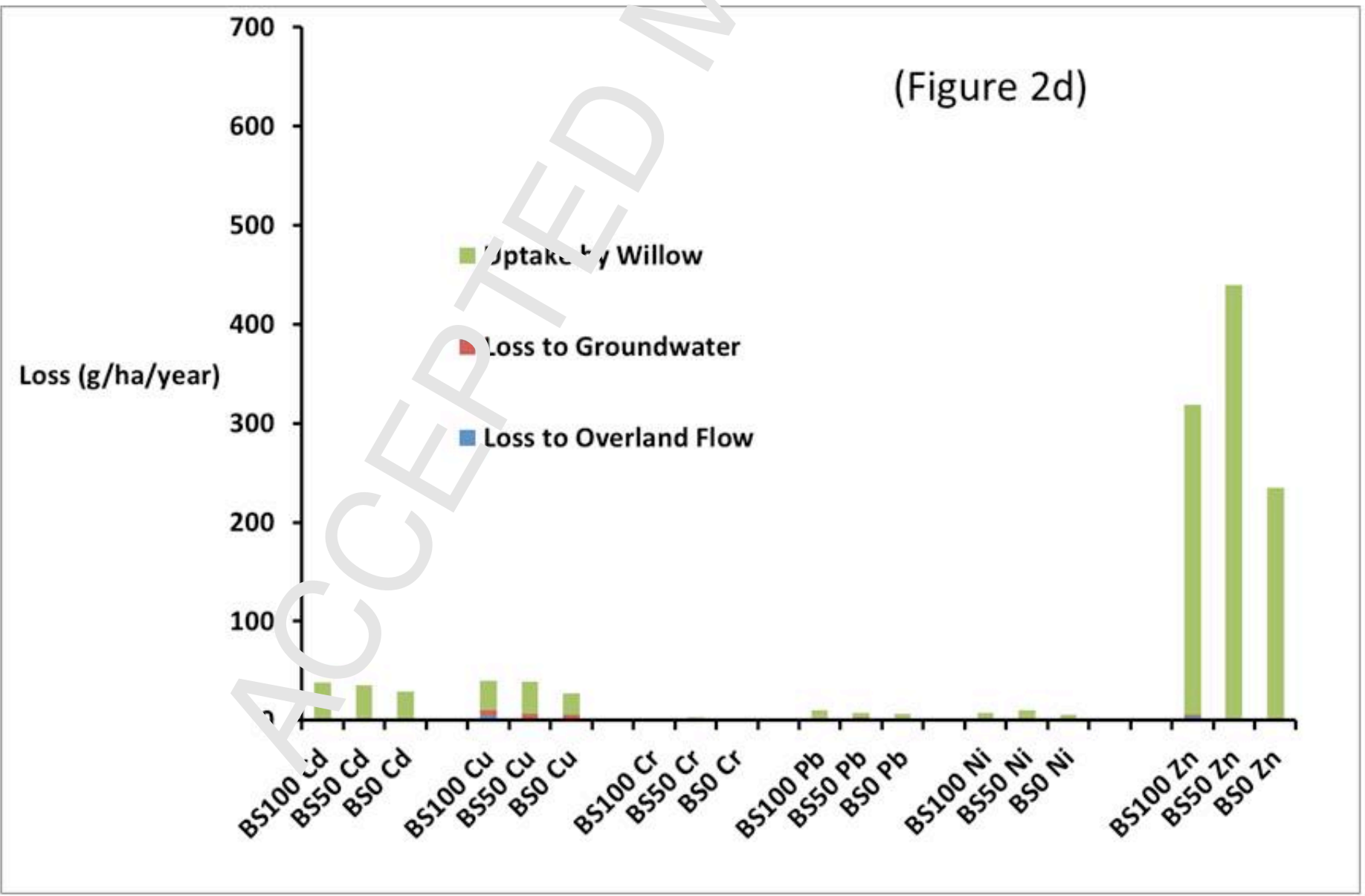


The fate of nutrients and heavy metals in energy crop plantations amended $w^{i} \mathrm{n} \sim$ ranic byproducts

Highlights:

- The greatest inputs to the system came from the soil, the sm …st inp $\quad$ was from atmospheric deposition.

- The largest output from the system was crop take up; the cma.. ${ }^{-+\cdot}$. as loss to OLF.

- Organic byproducts can enhance energy crop nutrition with' u 'eleterious environmental consequences. 